\title{
A media luz. Grabados de la Prehistoria Reciente en abrigos galaicos
}

\author{
In half light. Later Prehistoric carvings in Galician rock shelters
}

\author{
Ramón Fábregas Valcarce (*) \\ Carlos Rodríguez Rellán (*)
}

\section{RESUMEN}

La prospección sistemática de arte rupestre en el Ayuntamiento de Porto do Son (A Coruña) ha permitido la localización de casi dos centenares de grabados, dos de ellos en abrigos graníticos. A estos últimos se suman otros dos casos en las comarcas occidentales de Galicia. La temática presente es idéntica a la del arte galaico al aire libre, datado grosso modo en el III milenio a.C. Estos hallazgos plantean, por otra parte, la intencionada restricción física sobre la visualización de este fenómeno. La convivencia de motivos en el interior de cavidades con otros situados al aire libre e incluso en frisos verticales fácilmente perceptibles demuestra la variabilidad de estas manifestaciones y nos permite reflexionar sobre la audiencia a la que habrían estado destinadas las diferentes estaciones rupestres.

\begin{abstract}
The systematic survey of rock art in the area of the town council of Porto do Son (A Coruña) has allowed us to find nearly two hundred carved surfaces, two of them located within rock shelters. Two other examples in the Western regions of Galicia must be added to those. The motifs inside the rock shelters are exactly the same as those found in the open-air petroglyphs, which can be roughly dated to the third millennium $B C$. These finds attest to the existence of an intentional constraint on the visibility of these graphic manifestations. The coexistence of motifs inside cavities and others located outdoors, even on fairly conspicuous vertical friezes, shows the variability of this phenomenon and allows us to reflect on the different audiences at which the rock sites would have been aimed.
\end{abstract}

(*) Dpto. de Historia I, Facultade de Xeografía e Historia, Universidade de Santiago de Compostela. Praza da Universidade 1. 15782 Santiago de Compostela.

Correos e.: ramon.fabregas@usc.es; carlos.rellan@usc.es

Recibido: 21-III-2011; aceptado: 6-V-2011.
Palabras clave: Arqueología del paisaje; Prehistoria Reciente; Arte esquemático; Espacio ritual; Armas; Caza.

Key words: Landscape Archeology; Recent Prehistory; Schematic Art; Ritual Space; Weapons; Hunting.

\section{INTRODUCCIÓN}

Uno de los aspectos que más atención ha concitado en los estudios sobre arte prehistórico realizados en las últimas décadas tiene que ver con el público al que las manifestaciones artísticas se habrían dirigido. Como acertadamente señala R. Bradley (2009: 8), pocas veces resulta posible deducir el significado de las imágenes del pasado sin la ayuda de documentación escrita, pero es factible abordar la relación entre las grafías y la gente que las contempló en su momento. En este sentido, podría plantearse la diferencia esencial que existe entre el arte ejecutado al aire libre y aquel realizado en el interior de cuevas o locales artificialmente cerrados (megalitos o viviendas por ejemplo), pues la segunda opción propone una limitación evidente respecto al número de observadores y circunstancias (iluminación o sonoridad por ejemplo) de su visualización. No obstante, como veremos, esta oposición tan definida está abierta a la matización toda vez que, por ejemplo, en el exterior pueden darse situaciones que modulen esa mayor 'apertura', no sólo en nombre de las convenciones sociales sino en función de la disposición de los paneles decorados o la microtopografía del entorno de éstos, que pueden plantear restricciones a la 'publicidad' de las manifestaciones artísticas o imponer perspectivas o recorridos específicos para su contemplación. 
Por otra parte, la discreción o recogimiento asociados a las imágenes ejecutadas en el interior pueden estar compensados, siquiera parcialmente, por su vinculación a monumentos o formaciones geológicas llamativas, que actúen como referentes en el paisaje. Al mismo tiempo debemos tener en cuenta que las cuevas y abrigos pueden tener múltiples usos, desde los de naturaleza ceremonial al simple empleo como refugio más o menos ocasional.

Las consideraciones precedentes resultan de interés a la hora de abordar las expresiones gráficas encuadradas bajo la denominación de petroglifos galaicos, un grupo artístico cuya cronología coincide básicamente con el III milenio AC, si bien con extensiones temporales anteriores y posteriores a dicho marco cronológico (Fábregas 2010). Los petroglifos tienen como una de sus señales distintivas el comparecer sobre rocas al aire libre, generalmente poco conspicuas, aunque existan excepciones a esta norma como en el gran panel del Outeiro dos Lameiros (Baiona, Pontevedra), cuya imaginería y emplazamiento lo aproximan al arte esquemático, en un área (SO de Galicia) donde abundan los indicios de interacción e influencia mutua entre ambos grupos artísticos (Bradley y Fábregas 1999).

En este trabajo presentaremos varios casos en los que motivos clásicos entre las insculturas gallegas, como combinaciones circulares de cierta complejidad o representaciones de zoomorfos, han sido grabados en oquedades y abrigos graníticos. Una última estación (Pedra Xestosa) tiene la peculiaridad de plasmar en un mismo afloramiento rocoso una aparente convivencia entre paneles grabados al aire libre y otros protegidos por una visera pétrea.

\section{LOS ABRIGOS Y CAVIDADES GRANÍTICAS DURANTE LA PREHISTORIA RECIENTE EN GALICIA}

La escasez de cuevas en la mayor parte del territorio gallego, consecuencia de la reducida existencia de formaciones calizas (concentradas en el sector oriental de las provincias de Lugo y Ourense) y el dominio casi absoluto que las litologías plutónicas tienen en buena parte de esta comunidad, ha convertido a los abrigos graníticos en una alternativa puntual para las ocupaciones humanas a lo largo de la Prehistoria, las cuales han tenido una naturaleza variable, desde aquélla estrictamente doméstica a otra posiblemente funeraria o ritual.

En este sentido, es conocida la presencia humana en abrigos graníticos desde, al menos, el Paleolítico Superior y el Epipaleolítico, con yacimientos como los de Pena Grande (Vilalba, Lugo) (Ramil y Ramil 1995). Posteriormente, en el Neolítico, existen también evidencias puntuales de actividades humanas al interior de este tipo de cavidades, caso de A Cunchosa (Cangas, Pontevedra) (Suárez 1997), prolongándose éstas incluso hasta bien entrada la Edad del Hierro, como en Os Pericos (Ribeira, A Coruña) (Vilaseco y Fábregas 2008) o Cova dos Mouros (Oímbra, Ourense), en la que también podrían atestiguarse ocupaciones anteriores (Gómez y Vázquez 2009). Junto a estos ejemplos, en los que las ocupaciones tendrían un carácter probablemente doméstico, encontramos casos como los de Arca dos Penedos (Baltar, Ourense) (Eguileta et al. 1993-1994) o la gran cavidad de O Folón (Vigo, Pontevedra) (Rodríguez et al. 1996-1997) donde la parquedad de material (varios fragmentos de campaniforme cordado en el primero y un vaso de cerámica incisometopada tipo Penha y sendos útiles pulimentados en el segundo) podrían apuntar a la posibilidad de deposiciones votivas o bien de enterramientos de los que, debido a las condiciones locales extremadamente ácidas, no haya quedado ninguna evidencia orgánica. Resulta interesante que, a día de hoy, no se hayan documentado evidencias de arte, a pesar de que -por ejemplo- en concreto en O Folón, la formación en la que se sitúan las cavidades tiene un buen número de paneles rupestres al aire libre.

\section{GRABADOS RUPESTRES EN EL INTERIOR DE ABRIGOS}

Las investigaciones realizadas en diversos puntos de la costa occidental gallega, en colaboración con especialistas y aficionados locales, nos permitieron localizar más de un centenar de estaciones rupestres, cuatro de ellas (Fig. 1) situadas en el interior de abrigos o viseras graníticas de distinta entidad y con un carácter más o menos reservado.

Con anterioridad a estos trabajos, contábamos tan solo con la referencia a la existencia de grabados en cinco cavidades de Corme (A Coruña), entre las que destaca Petón da Campaíña, una 

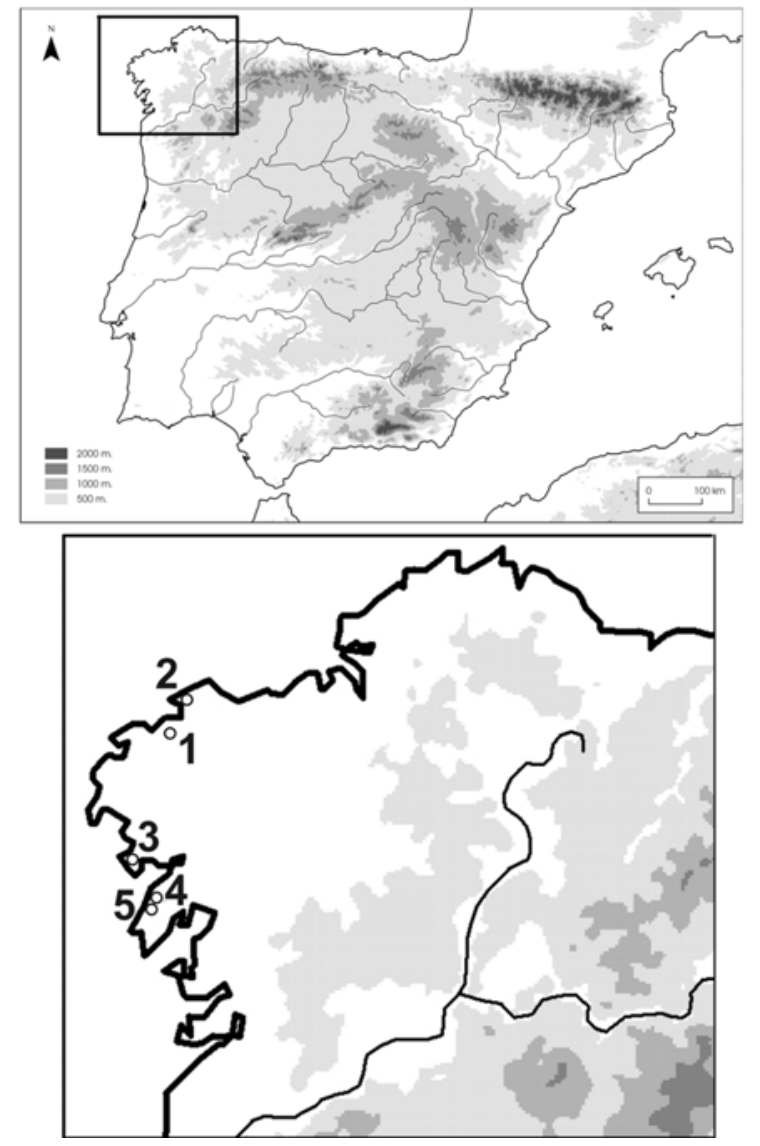

Fig. 1. Situación en la Península Ibérica de los principales abrigos con arte rupestre de A Coruña mencionados en el texto: 1. Pedra Xestosa (Laxe); 2. Petón da Campaíña (Corme); 3. Outeiro de Rixidores (Carnota); 4. Calderramos y 5. Rego de Corzo (Porto do Son).

enorme visera granítica en cuyo interior se han documentado motivos sencillos (cazoletas, líneas y círculos simples), amén de otros de cronología probablemente histórica (Mañana y Santos 2002). A éstos habría que sumar los abrigos de Peneites (Nigrán) y Pedra Cavada (Gondomar), en Pontevedra, en cuyo piso rocoso se practicaron respectivamente una y dos pequeñas piletas de forma cuadrangular, para las que contamos con paralelos al aire libre repartidos a lo largo de más de medio centenar de puntos del suroeste gallego, a menudo asociadas a grabados prehistóricos (Vázquez Rozas 1998; Fábregas 2010).

La principal novedad de las estaciones que ahora presentamos estriba en que se documenten, por primera vez en el interior de abrigos, los motivos clásicos del corpus rupestre prehistórico al aire libre: combinaciones circulares complejas y zoomorfos.

Pedra Xestosa (Laxe, A Coruña): se sitúa al noroeste de Galicia, en un lugar que hasta hace muy poco se creía huérfano de representaciones naturalistas (Rodríguez et al. 2010). La estación se encuentra sobre un gran batolito granítico en torno a $\operatorname{los} 3 \mathrm{~m}$ de altura y con su eje mayor orientado en dirección NE-SO. Es un afloramiento no especialmente conspicuo situado en la ruptura cóncava de una pequeña vaguada protegida de los vientos del norte (Fig. 2).

En la parte sur del afloramiento existe un pequeño abrigo de apenas un metro de ancho y poco
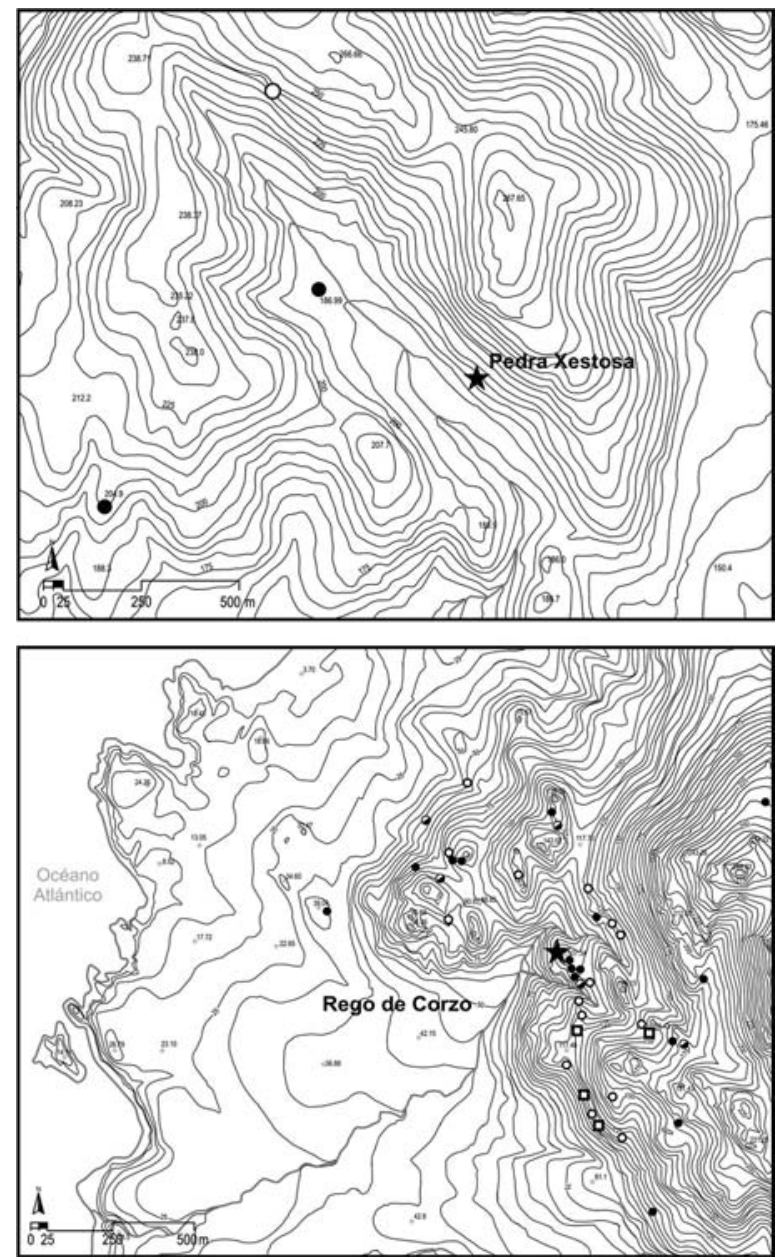

Fig. 2. A Coruña: planos de situación de los abrigos de Pedra Xestosa (Laxe) y Rego de Corzo (Porto do Son); círculos: paneles horizontales; cuadrados: paneles verticales / negro: motivos geométricos; blanco: motivos naturalistas (base: Mapa Topográfico Nacional, escala 1:5.000). 

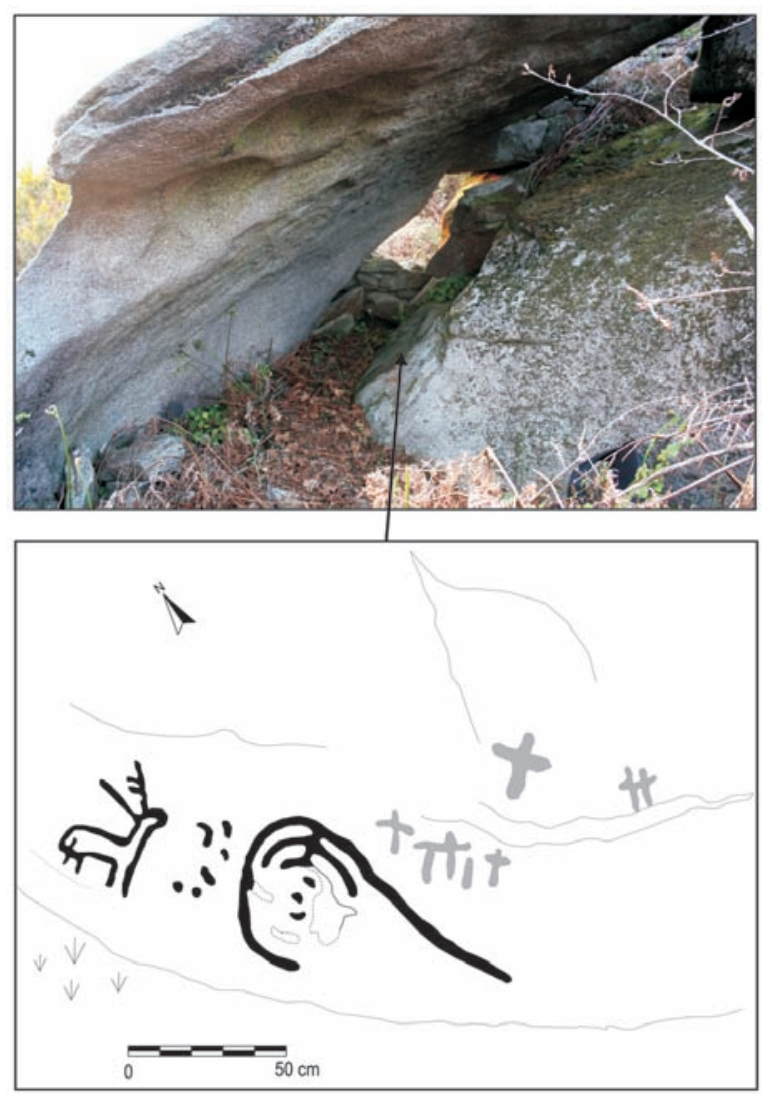

Fig. 3. Detalle del abrigo de Pedra Xestosa (Laxe, A Coruña) y del calco de los motivos documentados en su interior.

más de $1,5 \mathrm{~m}$ de altura, conformado por un tafone originado por la erosión eólica (Fig. 3). En la pared de esta minúscula cavidad se documentó un zoomorfo con cornamenta amén de una combinación circular incompleta, único motivo abstracto presente en toda la estación. También se observan varios cruciformes claramente modernos. Otro panel se sitúa en la parte externa de la roca que actúa de cubierta del abrigo (Fig. 4) y se compone de al menos seis cérvidos presididos por un gran macho. Varios de estos animales han sido representados en actitudes naturalistas, como el berreo o el olisqueo de genitales. El tercer conjunto, el más complejo de la estación, se localiza sobre una pared totalmente vertical de casi $2 \mathrm{~m}$ de altura y $6 \mathrm{~m}$ de longitud donde se ha identificado una escena de caza: seis cérvidos se enfrentan a otras cuatro o posiblemente cinco figuras de animales de mayor esquematismo, interpretados como cánidos, así como a un antropomorfo. La composición está dominada por la confrontación entre el cérvido de mayor tamaño y cornamenta más desarrollada y el antropomorfo, cuyo brazo delantero se proyecta de modo antinatural hacia la cabeza del gran animal. Ello, con toda probabilidad, representa algún tipo de arma, posiblemente una lanza, como también podrían serlo las líneas horizontales dispuestas frente al cérvido situado en el extremo derecho de la escena. Entre la figura humana y el gran ciervo, por encima de ambos, aparece una imagen incompleta - iun posible ídolo o divinidad protectora?- paralelizable con otras conocidas en estaciones gallegas (Santos 2005a) así como en la pintura del dolmen de Orca dos Juncais (Viseu, Portugal), con el que este panel guarda notables similitudes.

Rego de Corzo VI (Porto do Son, A Coruña): el abrigo se sitúa en las estribaciones occidentales de la Sierra del Barbanza, en la zona de transición hacia la amplia plataforma costera (Fig. 2). Se encuadra en un área de unas 40 ha (Outeiro Campelos-Rego de Corzo), en la que se ha documentado un considerable número de estaciones rupestres, algunas de gran monumentalidad, situadas en puntos desde los que se domina visualmente los valles que desembocan en el océano (Fig. 5A). Dicha zona se caracteriza por numerosos batolitos graníticos que conforman un relieve escalonado y compartimentado por pequeñas gargantas por donde circulan cursos de agua en torno a los cuales se concentran buena parte de los grabados. Estos accidentes delimitan, a Norte y Sur, un espolón en cuya ladera occidental se encuentra el abrigo, con su entrada orientada al Oeste y un interior de poco más de $2 \mathrm{~m}$ de ancho, $1,5 \mathrm{~m}$ de profundidad y $50 \mathrm{~cm}$ de altura (Fig. 6).

En el suelo rocoso de la cavidad se localizan cuatro zoomorfos, probablemente cérvidos, dos de ellos incompletos. Éstos se orientan mayoritariamente hacia la derecha, con la excepción del mayor y mejor conservado de los animales. Pese a estar a cubierto, los surcos presentan un cierto grado de erosión, resultado de la existencia de pequeñas aperturas en la parte sureste del abrigo por las que penetra el agua de lluvia. No obstante, su surco relativamente estrecho e irregular parece sugerir que en su elaboración se habría empleado la técnica del piqueteado. Esta información resulta de gran importancia desde un punto de vista técnico, pues dado el alto grado de erosión que afecta a los grabados rupestres galai- 


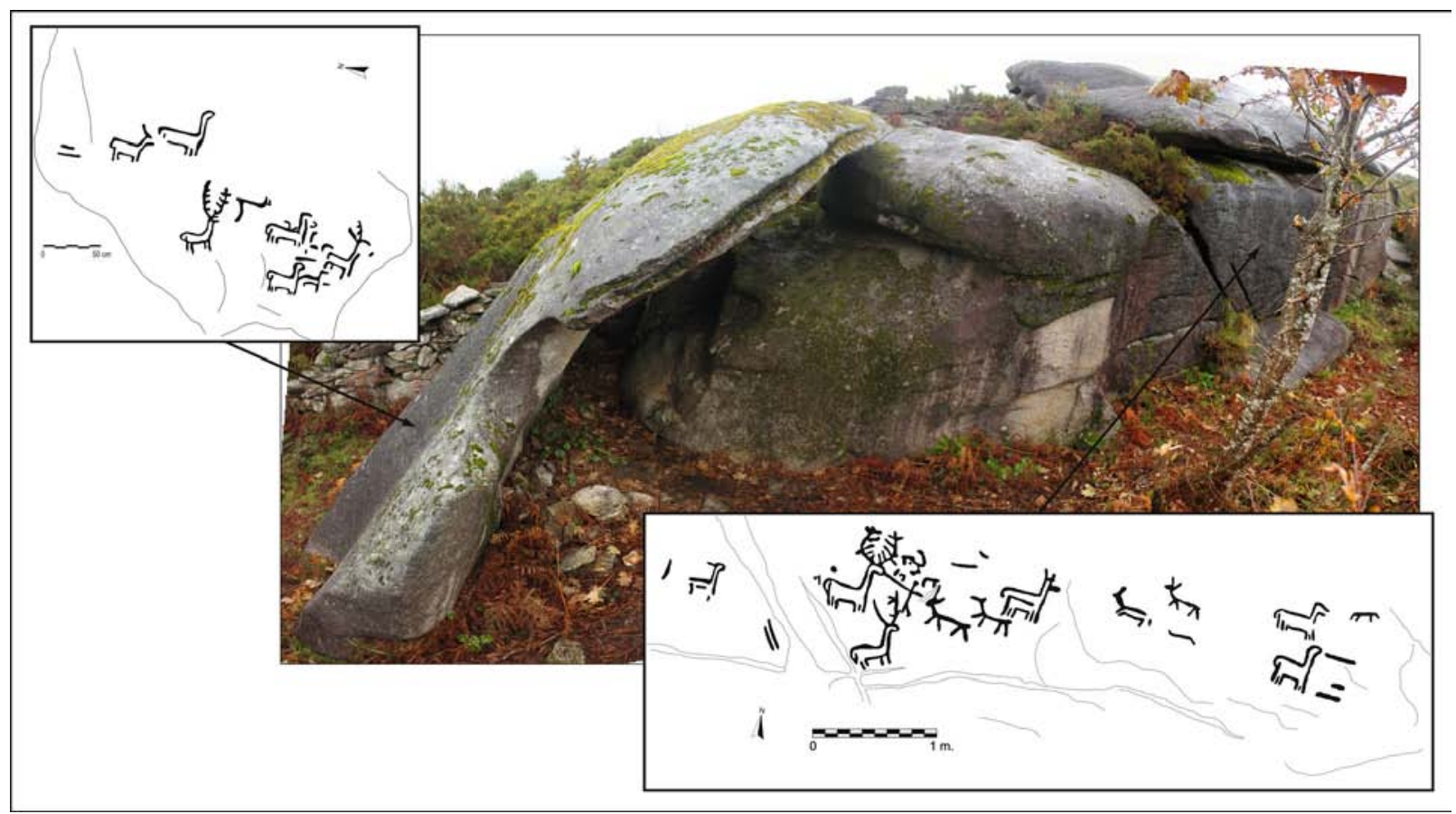

Fig. 4. Aspecto general de Pedra Xestosa (Laxe, A Coruña) con la situación y calco de los paneles situados al aire libre.

cos al aire libre, nunca se ha podido determinar con seguridad la técnica exacta empleada para su realización.

Calderramos (Porto do Son, A Coruña): el abrigo se localiza a $3 \mathrm{~km}$ al Norte de Rego de

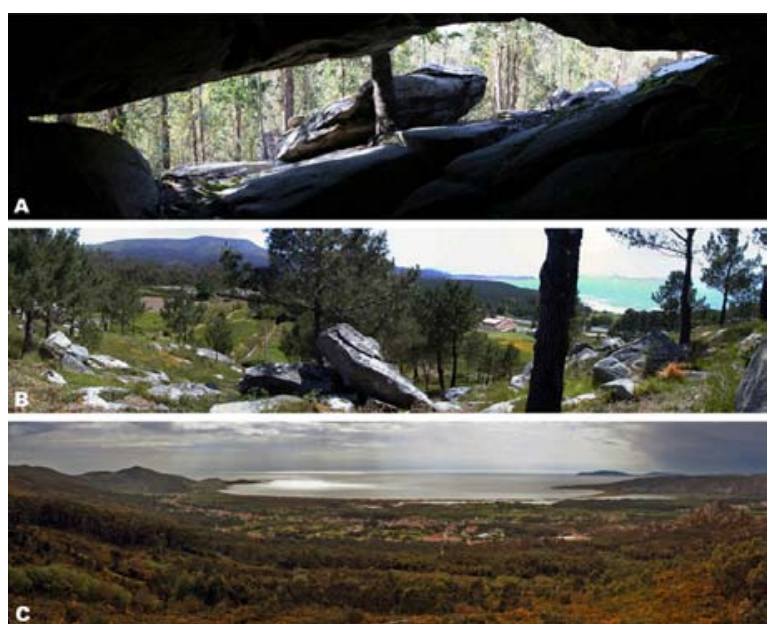

Fig. 5. A Coruña: perspectivas desde el interior del abrigo de Rego de Corzo (Porto do Son) (A), así como desde la entrada de los abrigos de Calderramos (Porto do Son) (B) y Outeiro de Rixidores (Carnota) (C).
Corzo, también en la zona inmediata de transición hacia la plataforma costera (Fig. 7). Se ubica dominando en altura una pequeña vaguada que desciende en dirección suroeste hacia la costa atlántica. Esta hondonada, sobre la cual el abrigo ejerce un evidente control visual (Fig. 5B), en la actualidad está profundamente modificada por la construcción de terrazas para el cultivo, si bien antiguamente servía de cauce para un pequeño curso de agua.

El abrigo (Fig. 8) consiste en una diminuta cavidad granítica, abierta hacia el sureste, de poco más de $2 \mathrm{~m}$ de ancho por apenas uno de profundidad, mientras que su altura no supera los $70 \mathrm{~cm}$. En su origen tendría un carácter mucho más cerrado y reservado, perdido a raíz de las actividades de cantería tradicional que removieron parte de la visera pétrea.

Los motivos, parcialmente al aire libre, se sitúan en el suelo inclinado en dirección a la pendiente. El conjunto comprende una multitud de surcos que no conforman ninguna figura reconocible y que, en ocasiones, han aprovechado las diaclasas de la propia roca. Junto a éstos, contamos con cazoletas de diversos tamaños y profundidades así como varios motivos geomé-

Trab. Prehist., 69, N. ${ }^{\circ}$ 1, enero-junio 2012, pp. 80-102, ISSN: 0082-5638 doi: $10.3989 /$ tp.2012.12081 

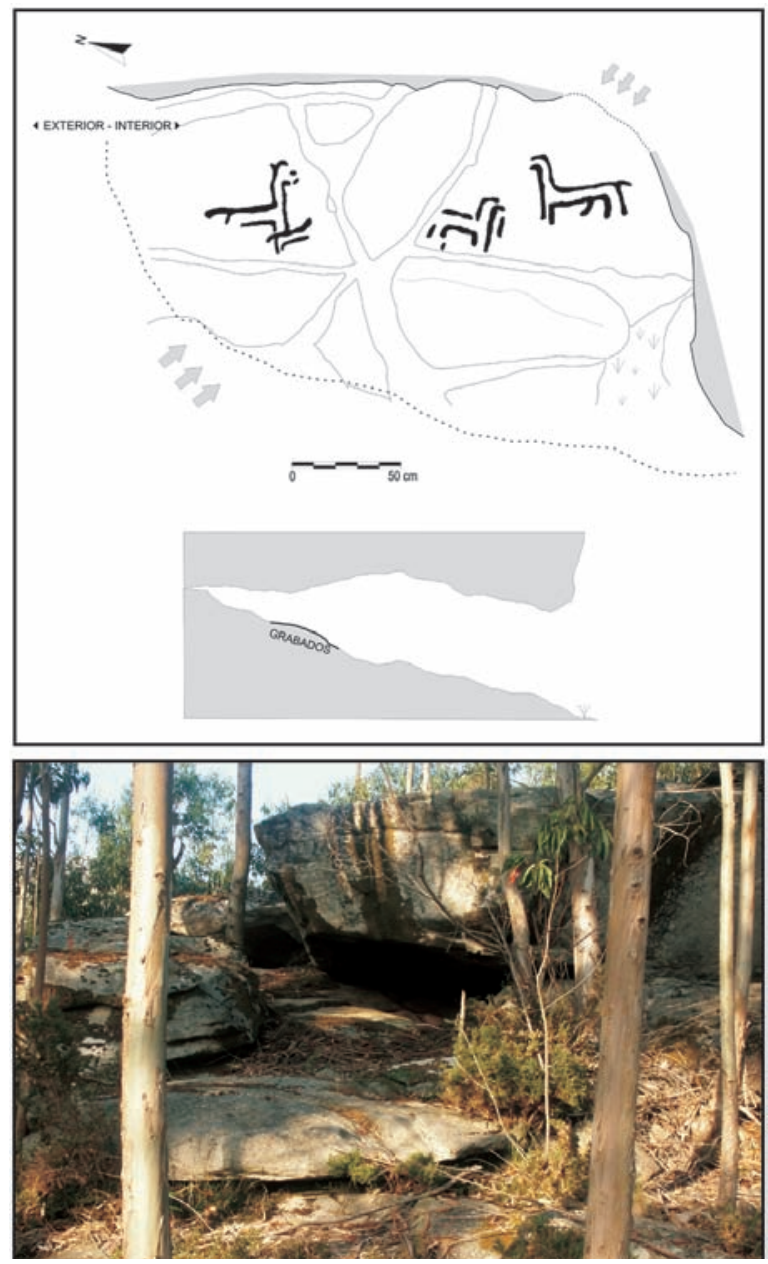

Fig. 6. Aspecto general del abrigo de Rego de Corzo (Porto do Son, A Coruña) y calco de los motivos documentados en su interior.

tricos, entre los que destaca una combinación circular incompleta situada en el interior del abrigo. Pese a haberse documentado señales recientes de fuego dentro de la cavidad, los grabados presentan un buen estado de conservación. Ello ha permitido identificar la técnica empleada para su ejecución: piqueteado en la combinación circular y buena parte de los surcos lineales, pudiendo observarse incluso los golpes individuales realizados durante el proceso, y pulido en varias cazoletas, fundamentalmente las de mayor tamaño. En el momento de su descubrimiento, se recogieron muestras del sedimento de su interior para su análisis si bien, lamentablemente, éstas no proporcionaron ningún resultado significativo.
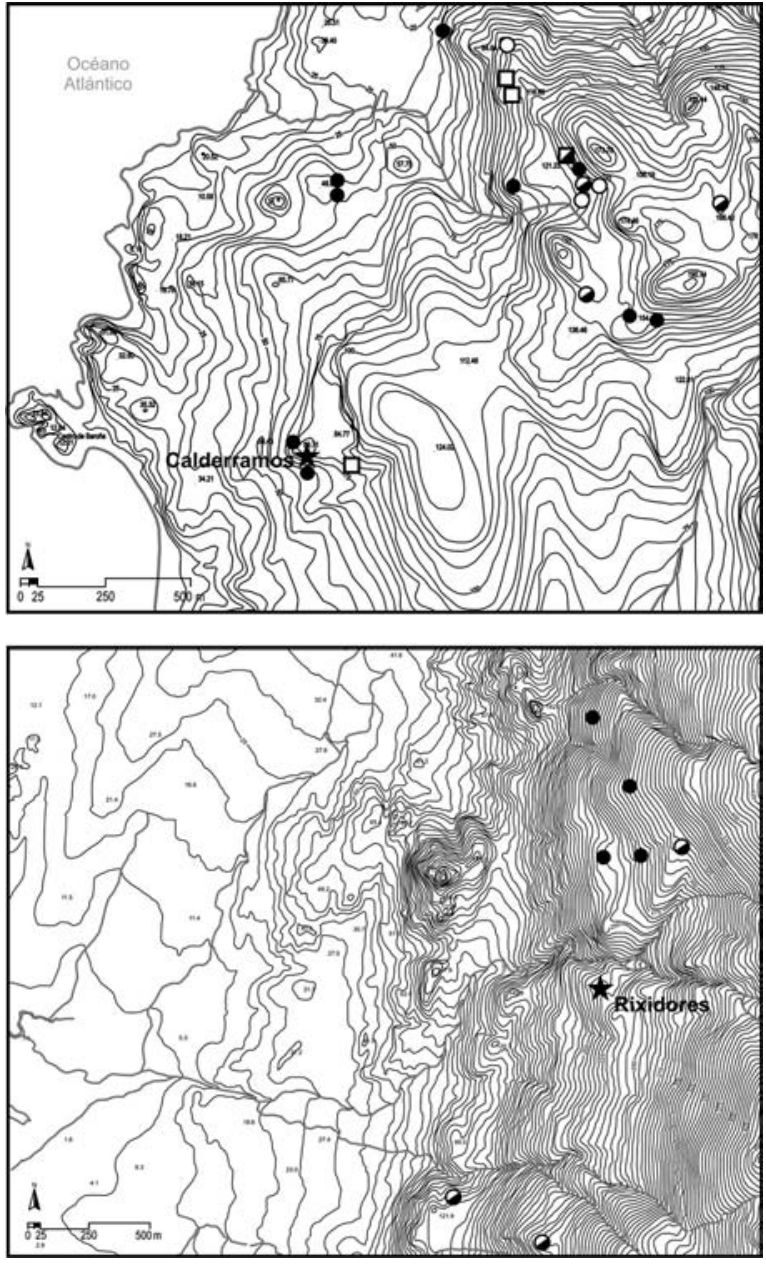

Fig. 7. A Coruña: planos de situación de los abrigos de Calderramos (Porto do Son) y Outeiro de Rixidores (Carnota); círculos: paneles horizontales; cuadrados: paneles verticales / negro: motivos geométricos; blanco: motivos naturalistas (base: Mapa Topográfico Nacional, escala $1: 5.000)$.

Outeiro de Rixidores (Carnota, A Coruña): el abrigo (Cernadas 2007) se sitúa en el sector inferior-medio de la ladera noroeste de una pequeña sierra cuya cota máxima en ese punto se sitúa en torno a los $490 \mathrm{~m}$. La estación se localiza sobre una terraza natural que supone uno de los pocos relieves suaves en un área caracterizada por su fuerte pendiente (Fig. 7). En las cercanías existe una pequeña vaguada por la que desciende, en dirección Oeste, un riachuelo. La orientación del abrigo ignora por completo dicha vaguada, para enfocarse hacia la amplia plataforma costera sobre la que goza de una espectacular perspectiva (Fig. 5C). 

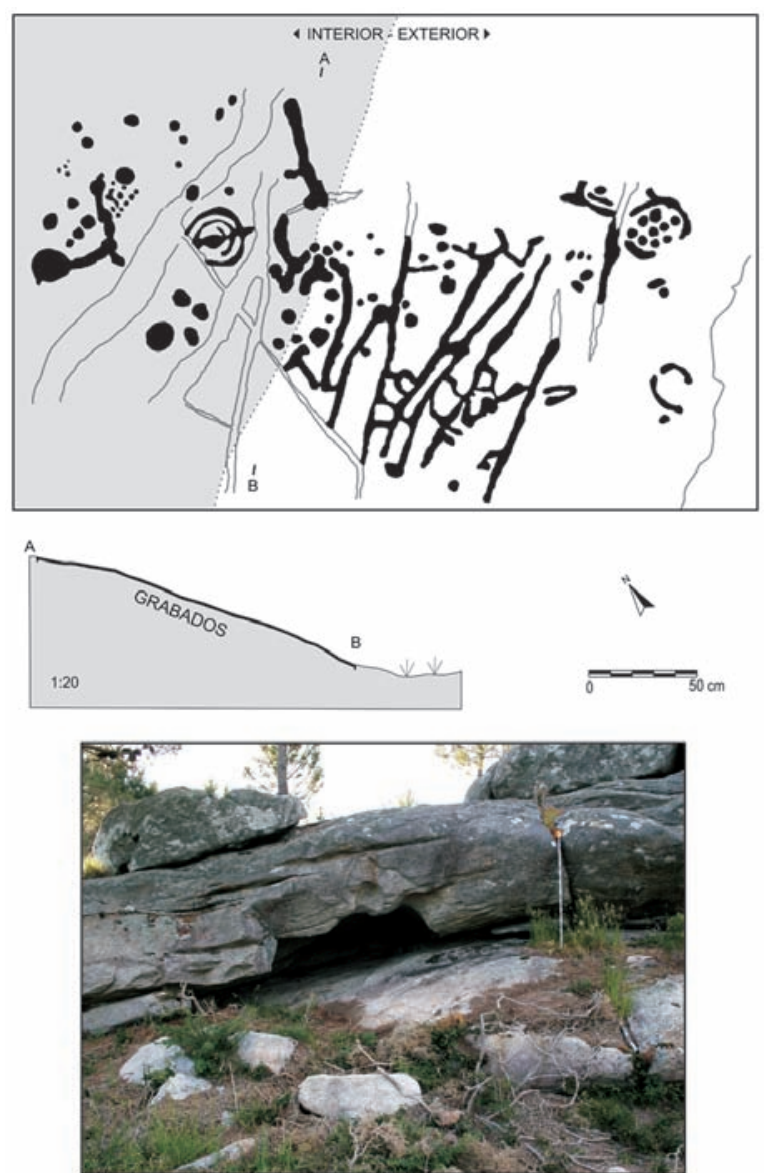

Fig. 8. Aspecto general del abrigo de Calderramos (A Coruña) y calco de los motivos documentados.

El grabado no se sitúa en un abrigo sensu estricto, sino más bien bajo una pequeña visera granítica naturalmente conformada por dos de los numerosos batolitos (Fig. 9) que componen la amplia y recortada masa granítica que domina las laderas de este punto de la costa occidental gallega. La naturaleza recogida u oculta de la estación está fuera de toda duda, pues la observación del motivo y del propio panel exige el acceso a la cavidad. Este carácter cerrado podría haber sido acentuado de manera artificial mediante la colocación de una laja granítica plana en la parte superior de la visera, si bien resulta difícil determinar si ésta fue colocada coetáneamente al proceso de grabado o bien en momentos posteriores, quizás por parte de pastores que buscaban abrigo.

El panel está conformado por una combinación circular de considerables dimensiones (78 $\mathrm{cm}$ de diámetro) situada en el suelo y orientada

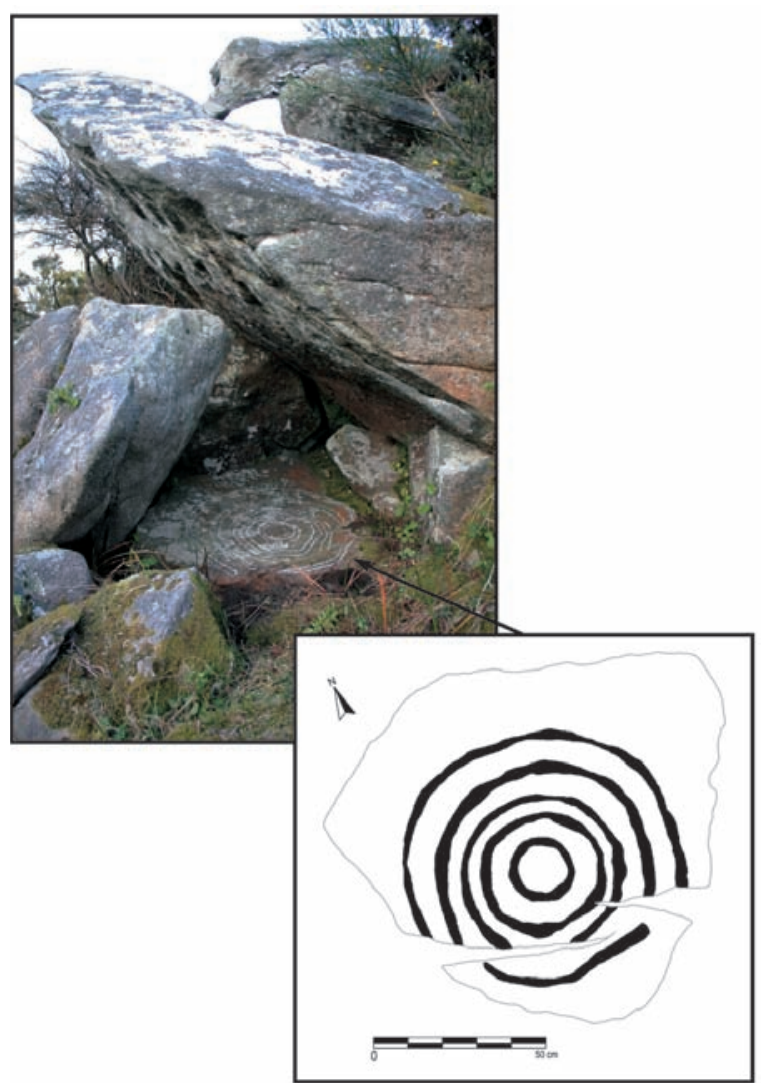

Fig. 9. Aspecto general de Outeiro de Rixidores (Carnota, A Coruña) y calco del motivo documentado en su interior.

según la pendiente. El grabado se ha visto condicionado por la existencia de una diaclasa que atraviesa la parte inferior del panel. La erosión del motivo ha sido considerable, debido a su exposición a los vientos procedentes del océano, siendo imposible determinar la técnica empleada en su ejecución.

\section{ARTE RUPESTRE GALLEGO AL AIRE LIBRE Y EN ABRIGOS}

Los abrigos que acabamos de describir comparten una característica: los grabados se han ubicado siempre en el suelo o bien en la parte baja de las paredes, mientras que sus zonas medias y altas fueron sistemáticamente ignoradas. Dicha circunstancia parece indicar una cierta trasposición al interior del abrigo de la lógica de grabado propia de buena parte del arte rupestre 
al aire libre, más que de la dinámica que puede observarse en los abrigos con arte esquemático y en las cámaras megalíticas, donde las representaciones evidencian una acusada verticalidad.

Hay más diferencias entre las estaciones al aire libre y en abrigos, referentes a la naturaleza y complejidad de sus grabados, las propias características internas de las cavidades, la ubicación de los mismos en el lugar y su facilidad de acceso. Los abrigos con arte rupestre documentados en Galicia no comparten -en cuanto a su ubicación- la mayoría de las características de los lugares con arte esquemático, donde muchas de las cavidades se sitúan en lugares difícilmente accesibles, lo que teóricamente habría limitado su contemplación. En nuestro caso, los abrigos comparten localización con otras insculturas al aire libre (Figs. 2 y 5), dominando valles fluviales y plataformas costeras desde las cuales se tendría una relativa facilidad de acceso a las estaciones. A pesar de ello, existen abrigos más fácilmente asequibles -como Pedra Xestosa o Calderramosque otros, como Rego de Corzo y, sobre todo, Outeiro de Rixidores.

Todos estos recintos tienen en común el reducido tamaño de su interior, siendo prácticamente imposible permanecer de pie o incluso agachado, debido fundamentalmente a que, salvo en Pedra Xestosa, no superan el metro de altura. Además, en Outeiro de Rixidores, Petón da Campaíña o Pedra Xestosa, este escaso tamaño viene acompañado de un deficiente aislamiento con respecto a los agentes atmosféricos, siendo frecuentes las filtraciones en su interior del agua de lluvia y de las corrientes de aire. Bastante más cerrados son Rego de Corzo y, sobre todo, Calderramos, hasta el punto de que, en el caso de este último, su insuficiente iluminación habría dificultado la visualización de los motivos.

Por todo ello, dichas cavidades serían muy poco adecuadas para su uso doméstico, aunque sí para la realización de rituales que requiriesen de una reclusión más o menos clara. Los abrigos gozan de ciertas cualidades que sin duda los habrían dotado de un carácter especial para los seres humanos de la Prehistoria. Ello muy verosímilmente habría sido clave para la ubicación en su interior de diversas manifestaciones artísticas, de modo que el simbolismo propio de ambas entidades -arte y abrigo- se potenciase mutuamente.

La oscuridad reinante en el interior de estas cavidades produciría una especie de "privación sensorial' que -en cierto sentido- habría detraído al observador de sus experiencias cotidianas, transportándolo a un mundo donde sus facultades sensitivas normales estarían alteradas. Probablemente por ello dichos recintos han sido considerados por muchas sociedades como lugares de transición entre dos mundos o realidades (Bradley 2009: 65). La naturaleza reducida y semi-cerrada de los abrigos habría aislado al individuo de los estímulos visuales y auditivos procedentes del exterior, facilitando la focalización de su atención hacia los grabados. Además, la escasa visibilidad en su interior habría exigido en alguna ocasión utilizar medios artificiales de iluminación o bien el uso del tacto para apreciar los motivos. La acústica reverberante habría potenciado la sonoridad producida por el golpeo y/o rasgado derivado del grabado así como los sonidos emitidos durante los ritos. Por otra parte, debido al reducido tamaño de los abrigos, es muy posible que durante todo el proceso el observador hubiese estado obligado a adoptar posturas forzadas e incómodas y a permanecer agachado o incluso tumbado.

Todas estas circunstancias habrían condicionado profundamente el nivel de intensidad y significado de la interacción entre arte y observador diferenciándola, hasta cierto punto, del tipo de experiencias que se podrían haber tenido en el arte rupestre al aire libre. En función de dichas disimilitudes, es muy posible que se hubiese otorgado al arte de las cavidades un significado e incluso un tipo de audiencia diferentes. Resulta tentador relacionar las especiales condiciones reinantes en el interior de los abrigos con la ya clásica asociación entre los procesos de producción del arte y los estados alterados de conciencia protagonizados, probablemente, por algún especialista de lo ritual (Lewis-Williams 2002). El arte rupestre galaico tampoco se ha sustraído a esa interpretación (Peña y Rey 2001), que podría apoyarse en la aparición de sustancias alucinógenas en los análisis de fitolitos realizados en algún petroglifo gallego (Fábregas 2010), si bien la vinculación cronológica de las mismas al momento de uso de los grabados no está asegurada (Guerra y López 2006). Por otro lado, no han sido pocos los autores (Kehoe 2000; Bahn 2001; Insoll 2004) que han criticado la vinculación establecida por algunos investigadores (Lewis-Williams 2002) entre arte, estados alterados de consciencia y chamanismo, señalando lo inapropiado de la aplicación general 
del último término, hecho que también podría extenderse al caso gallego.

\section{PERCEPTIBILIDAD DEL ARTE RUPESTRE GALAICO}

De modo general, se ha caracterizado al arte rupestre galaico, en tanto que ubicado al aire libre, como un fenómeno con una muy limitada imposición de restricciones para su contemplación, en contraste con el arte megalítico. Tradicionalmente se ha considerado a los petroglifos como un elemento abierto, fácilmente perceptible y accesible prácticamente a todo aquel que se moviese por el paisaje prehistórico. En consecuencia, estos grabados han sido asociados a un tipo de audiencia muy amplio y poco especializado con la excepción - quizás- de los grabados de armas, a menudo vinculados a grupos o cofradías de guerreros (Vázquez Varela 2000).

La documentación de arte en el interior de abrigos introduce una vuelta de tuerca en esta visión, pues su divergencia con respecto a los grabados al aire libre sería, en cierto modo, la misma que se propone entre petroglifos y arte megalítico: su naturaleza restrictiva y el tipo de audiencia al que estarían destinados (Bradley 2009: 120). La ubicación de los grabados en el interior de cavidades evidencia una voluntad efectiva por controlar el tamaño y la propia composición de los agentes involucrados $\mathrm{y}$, lo que consideramos muy importante, una clara pretensión de 'ocultación' de las representaciones.

El afán de ocultación evidenciado por estos petroglifos indica que debe relativizarse, al menos en parte, el papel que de modo general se le ha atribuido al arte rupestre galaico como 'marcador del paisaje'. Este tipo de concepciones vinculan el supuesto carácter abierto y la elevada perceptibilidad del arte rupestre al aire libre con audiencias muy amplias que, superando incluso a la comunidad creadora, abarcarían en parte a grupos vecinos y rivales.

En este sentido, los trabajos de T. Ingold (1987) y M. Casimir (1992) han tenido un enorme calado en la concepción del arte rupestre galaico como un elemento articulador y/o normativo del uso del espacio por parte de sociedades productoras aún con un alto grado de movilidad (Bradley 1997). En función de dichas interpreta- ciones, los petroglifos habrían sido herramientas de comunicación básicamente 'intergrupal', destinadas a mediar en el uso del paisaje por parte de dos o más poblaciones vecinas, estableciendo el acceso preferente o exclusivo por parte de un grupo determinado a un lugar económica y/o simbólicamente importante. Dicha interpretación convertiría al arte rupestre en una especie de código de señales o mensajes que funcionaría a modo de intercambio fijo de impresiones entre sociedades que no estarían en contacto directo de modo frecuente. Otros autores han remarcado, no obstante, que parte de esta información habría ido destinada también a los propios miembros de la comunidad, a modo de transmisor 'intergeneracional' de información útil vinculada generalmente a la explotación de los recursos del territorio circundante (Taçon 1994).

\subsection{Visibilidad y perceptibilidad}

Al abrigo de interpretaciones como las que acabamos de exponer, en las últimas décadas en gran número de investigaciones (Bradley et al. 1994; Santos 1999) las estaciones rupestres han sido analizadas fundamentalmente en el marco del paisaje circundante, a través del estudio de su distribución espacial, así como de su relación con vías naturales de tránsito (collados y vaguadas) y puntos de interés para su explotación económica por parte de las comunidades prehistóricas (valles fluviales y costeros, etc.). Sin embargo, muy pocas veces se ha analizado en profundidad la naturaleza e intensidad de la interacción entre estaciones rupestres y territorio circundante, así como tampoco se ha prestado demasiada atención a las estrategias y mecanismos por medio de los cuales dicha interacción podría haber sido modulada.

A tenor de nuestra experiencia, consideramos que la interacción entre petroglifos y paisaje se habría mediado a través, fundamentalmente, de dos conceptos: su visibilidad y su perceptibilidad. El primero hace referencia a la cantidad de lugares dominados o controlados visualmente desde un petroglifo determinado. La perceptibilidad define la facilidad para identificar desde el entorno circundante la roca $\mathrm{y} / \mathrm{o}$ los motivos de un determinado petroglifo así como la distancia desde la que unos $\mathrm{u}$ otros pueden ser captados. Ambos conceptos no tienen por qué ser equivalentes, pues existen muchas estaciones a ras de suelo

Trab. Prehist., 69, N. ${ }^{\circ}$ 1, enero-junio 2012, pp. 80-102, ISSN: 0082-5638

doi: $10.3989 /$ tp. 2012.12081 
apenas perceptibles al alejarnos unos metros pero desde las que se ejerce un gran dominio visual del entorno.

La visibilidad ha sido uno de los aspectos al que, en general, mayor importancia se ha prestado en el análisis espacial del arte rupestre al aire libre en Galicia (Bradley et al. 1994; Santos 1999; Peña y Rey 2001). Ésta depende prácticamente en exclusiva de la ubicación en el paisaje de una estación concreta, de tal manera que si ésta se sitúa en lugares, como una ladera, contará con un amplio dominio visual sobre las cotas inferiores. La visibilidad puede concentrarse sobre un lugar inmediato, como en una estación situada en un collado o una vaguada cuyo dominio visual se reduce fundamental o exclusivamente a dichos accidentes geográficos, o bien ser ejercida a media o incluso larga distancia, pudiendo llegar a controlarse varias decenas de kilómetros (Fig. 10). La diferencia entre ambos tipos de estaciones con respecto a su interactuación con el paisaje circundante sería evidente: aunque ambas controlan visualmente el mismo tipo de lugares, las primeras lo hacen desde el interior, por lo que es posible que hubiesen tenido un papel directo y real en la gestión de su tránsito y explotación. Las segundas, en cambio, ejercen un control desde una distancia elevada. Su interactuación con dichos lugares sería menos directa y quizás de una naturaleza más ritual o simbólica.

La perceptibilidad de los petroglifos ha suscitado mucho menos interés entre los especialistas y con frecuencia ha sido equiparada e incluso confundida con la visibilidad. Cuando ésta ha sido tenida en cuenta, la atención se ha centrado en la roca que sirve de soporte al petroglifo: su forma y tamaño así como su situación en un punto prominente del paisaje, como una colina o cerca de un gran afloramiento o un filón. Fuera de ello, rara vez se han valorado otro tipo de estrategias o mecanismos destinados a incrementar o reducir dicha perceptibilidad.

El impacto específico del panel grabado, tradicionalmente solo se ha estudiado a partir del incremento del tamaño de las figuras o, fundamentalmente, del carácter más o menos vertical de la superficie donde fueron grabadas, asociándose automáticamente los paneles verticales con una mayor perceptibilidad de sus motivos (Peña y Rey 2001: 207). Resulta obvio que el grado de verticalidad de un panel puede ser un recurso fundamental a ese respecto, si bien está lejos de ser su garante absoluto como tampoco se establece como la única herramienta para captar la atención.

Uno de los sistemas más efectivos para incrementar la percepción de los grabados vendría de
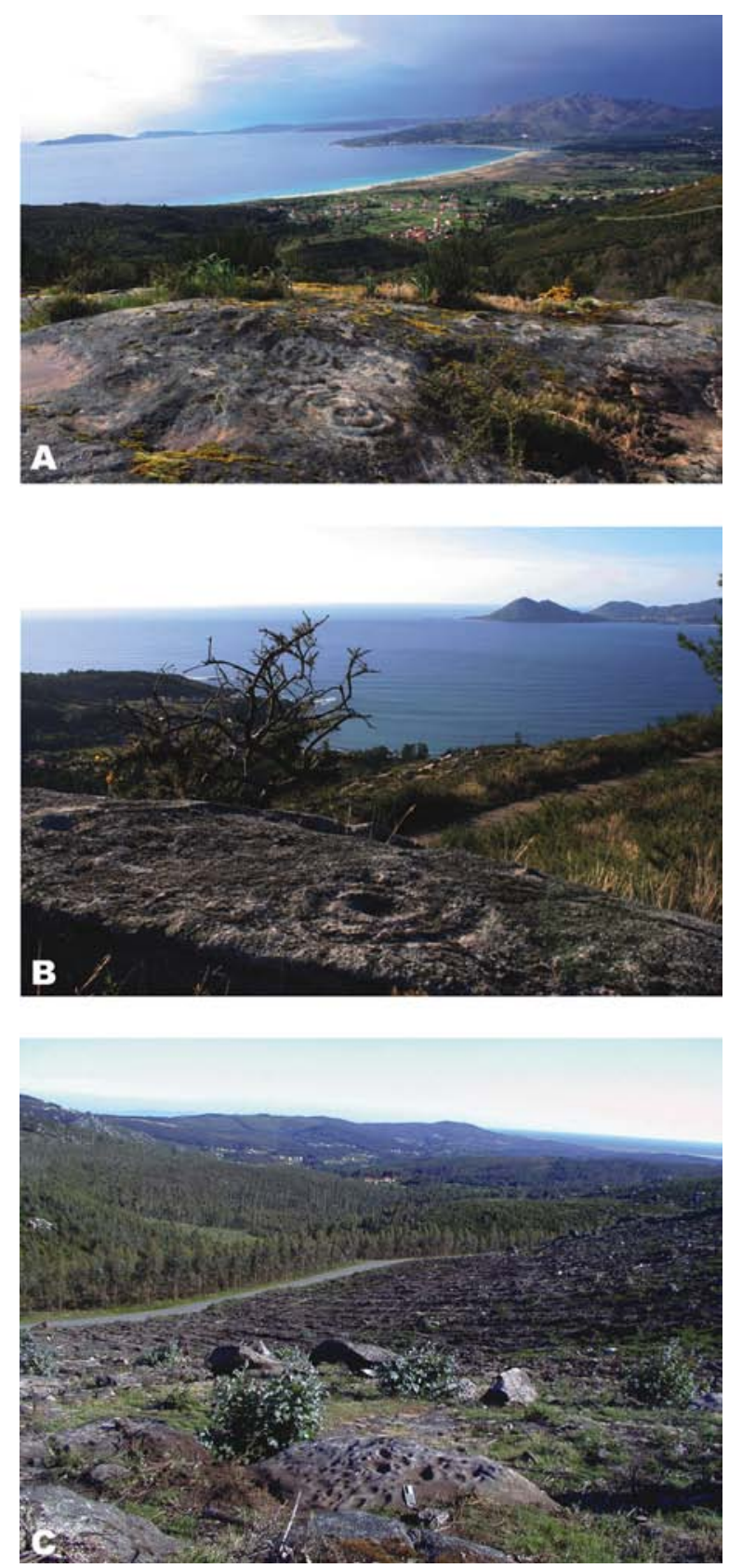

Fig. 10. A Coruña: A. Situación (en primer término) de los petroglifos de As Laxiñas (Carnota); B. Monte Dordo III y C. Cacharelas (Porto do Son), desde los cuales se goza de una gran visibilidad a larga distancia sobre amplios sectores del paisaje. 
aprovechar el contraste de tonalidad entre los surcos frescos y la superficie del panel. En el granito, la marcada coloración blancuzca de los grabados recién realizados habría hecho de la elección de una roca oscura un método idóneo para aumentar sustancialmente la perceptibilidad del conjunto (Fig. 11), incluso con independencia de la morfología de la roca y el panel o de las condiciones de luz existentes. Puede asumirse, además, la posibilidad de que los grabados fuesen repicados cada cierto tiempo (en el marco de diversos ritos o bien cada vez que se añadía un nuevo motivo al panel), de modo que el contraste habría podido perdurar durante períodos de tiempo relativamente amplios. La situación de muchos de los grandes petroglifos de nuestra comunidad (Peneda Negra, Gurita, etc.) en rocas con una superficie de color oscuro, puede no haber sido una circunstancia enteramente casual. No obstante, esta noción debe manejarse con cau-

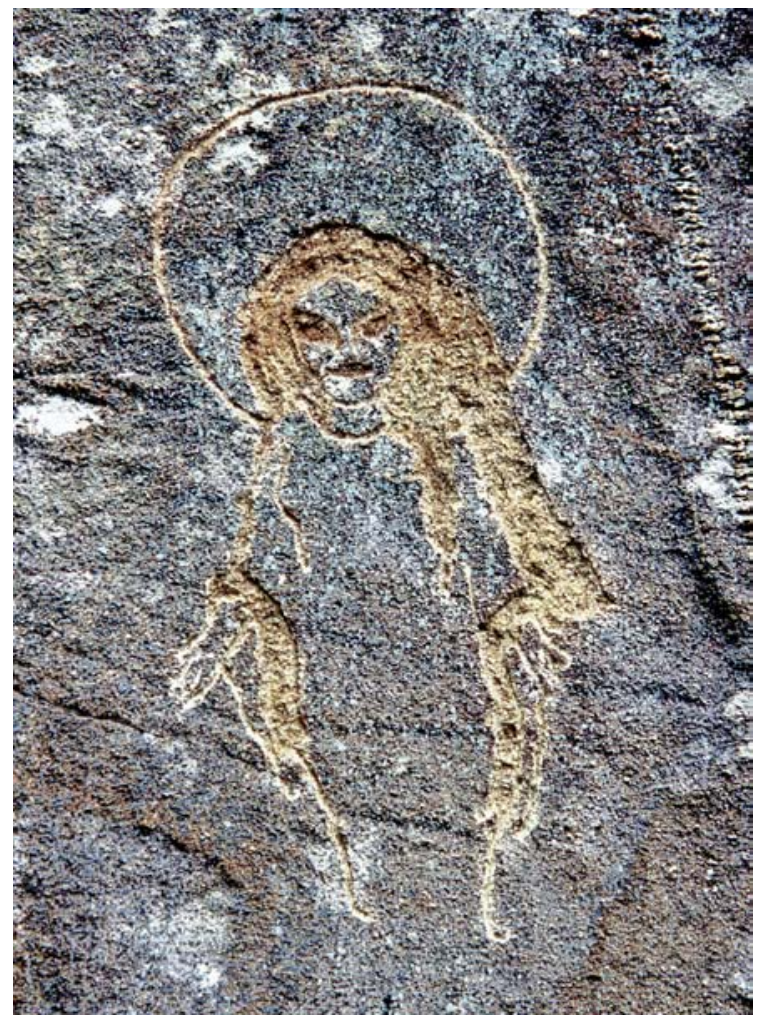

Fig. 11. Detalle de un motivo de factura reciente presente en la estación rupestre de Outeiro dos Lameiros (Baiona, Pontevedra) y en el que puede observarse el contraste de color entre los surcos y la superficie de la roca. tela, pues el aspecto superficial de una roca puede haber sido alterado dramáticamente durante los últimos 4.000 años debido a la actuación de agentes, como incendios forestales o líquenes.

Asimismo, este método puede haberse utilizado en el sentido contrario: el de ocultar los grabados. La elección de una roca con unas tonalidades claras habría hecho que -desde el mismo momento de su realización- los motivos hubiesen pasado prácticamente desapercibidos al alejarnos de ellos tan solo unos pocos metros, incluso en los paneles verticales. A cambio, al ser bañada por la luz solar, la coloración blanca habría conferido un aspecto brillante a la superficie de la roca que contrastaría con la oscuridad de las sombras que esa misma luz habría proyectado -a determinadas horas del día- en el interior de los surcos grabados, volviéndolos perfectamente visibles durante un lapso de tiempo concreto.

Lejos de considerar mera especulación la utilización consciente de los colores de las rocas como un medio de aumentar la perceptibilidad de un petroglifo, recordamos que se ha recurrido a ellos reiteradamente durante la Prehistoria (Scarre 2002; Tilley 2004), siendo especialmente evidente en el uso de minerales como el cuarzo en las corazas de los túmulos megalíticos para hacerlos más visibles (Criado y Vaquero 1993; Bradley 1998; Darvill 2002; Forteza et al. 2008).

La conjunción de éstas y otras variables tendría mucha importancia y habría cambiado en función de los objetivos y naturaleza con los que se concibiesen los distintos grabados y de la audiencia a la que se dirigiesen. Así, una estación con un carácter muy conspicuo se convertiría posiblemente en una referencia espacial de importancia $\mathrm{y}$, en consecuencia, jugaría un papel destacado en la concepción real y/o simbólica del paisaje compartida por los integrantes de las comunidades que hubiesen habitado ese entorno. Por el contrario, optar por reducir la perceptibilidad de ciertas estaciones quizás evidenciaría un afán de ocultación, como en los grabados situados en el interior de abrigos, haciéndolas visibles solamente a aquellos individuos con un conocimiento más exhaustivo del terreno. Dichos petroglifos podrían haber tenido una carga simbólica igual o más importante, pero reservada quizás a ciertos miembros de una comunidad concreta: la responsable de su realización.

Teniendo en cuenta las hipótesis que estipulan que buena parte de los petroglifos se configura-

Trab. Prehist., 69 N. $^{\circ}$ 1, enero-junio 2012, pp. 80-102, ISSN: 0082-5638

doi: $10.3989 /$ tp. 2012.12081 
rían como 'marcadores del paisaje' destinados a mediar en las relaciones entre grupos distintos por la explotación de determinados lugares, cabría esperar que su interacción con el paisaje potenciara tanto el dominio efectivo de esas zonas sujetas a derechos de uso, como la propia perceptibilidad del petroglifo. Al hacerlo, éste sería fácilmente observable por parte de los individuos ajenos a la comunidad, que serían una parte fundamental de la audiencia a la que el arte rupestre iría destinado.

Esta situación parece darse en estaciones con grabados de armas, las cuales habrían funcionado como importantes referentes en el marco del paisaje que ocupan. Sin embargo, los propios especialistas que defienden esta hipótesis (Bradley 1997; Vázquez Rozas 1995; Peña y Rey 2001) han sido conscientes de que, a menudo, este papel referencial parece mucho más difícil de discernir. En algunas áreas del arte rupestre galaico, dichas 'anomalías' (Bradley 1997) llegan incluso a ser mayoritarias en comparación con aquellos paneles más perceptibles o conspicuos (Peña y Rey 2001; Fábregas et al. 2010). De hecho, buena parte de los petroglifos tienden a situarse lejos de las vías de tránsito y de las zonas que otorgasen un control efectivo del acceso a las áreas de mayor interés para estas comunidades. Se emplazan más bien en puntos cuyo acceso dependería de un conocimiento profundo del terreno o de las pautas que operaban en la disposición del arte rupestre a lo largo del territorio (Peña y Rey 2001). De esta manera, el interés por su perceptibilidad parece haberse supeditado a la búsqueda de una visibilidad elevada.

Por todo ello, creemos que resulta difícil mantener que este tipo de grabados fuesen realizados pensando en una audiencia ajena a la propia comunidad. Fueron, más probablemente, una herramienta de 'autoconsumo' destinada a ser usada y entendida dentro del propio grupo que los habría creado. Estos petroglifos no habrían sido ideados, pues, para ejercer un papel de control directo y efectivo sobre el territorio -dejando claro a los miembros ajenos a la comunidad ese dominio- sino indirecto y simbólico, buscando reforzar la relación entre determinado(s) individuo(s) y el grupo del que formaría(n) parte con dicho lugar, así como reproducir o representar, a través de él, su propia concepción del mundo. Para ello no haría falta que interviniese esencialmente la contraposición con elementos ajenos a dicha comunidad.

\subsection{Relativizando lo perceptible}

El hecho concreto de que una estación rupestre se encuentre al aire libre no la hace equivalente a un elemento de observación abierta a todos cuantos frecuentaran el paisaje prehistórico gallego. La ausencia de barreras físicas evidentes para su detección no implica necesariamente la inexistencia de herramientas o métodos que, al volver prácticamente imperceptibles los grabados, limitaran su audiencia. La propia lectura de las imágenes del arte rupestre dista mucho de ser un simple asunto de sensaciones. Implica también conocimientos, recuerdos y una asociación icónica, procesos todos ellos culturalmente mediados (Tilley 2008: 38). Estas circunstancias no afectarían en exclusiva a la capacidad para interpretar las imágenes representadas sino al hecho mismo de su percepción.

Desde la perspectiva del mundo actual, marcado por una profunda naturaleza visual en la que la vista es un sentido primordial para nuestro desarrollo social, resulta difícil de entender la incapacidad para percibir determinadas imágenes por parte de un individuo concreto. Sin embargo, la experiencia del trabajo de campo en el medio rural gallego nos ha llevado al convencimiento de que, en el pasado, las sociedades campesinas tradicionales -inmersas en un mundo menos visualizado- habrían sido muchas veces incapaces de percibir parte de los motivos grabados en los petroglifos, pese a haber convivido con ellos durante siglos.

Las entrevistas realizadas entre los habitantes de mayor edad de las zonas inmediatas a las grandes concentraciones de arte rupestre nos confirmaron que la mayor parte de los grabados habían pasado totalmente desapercibidos para las comunidades campesinas gallegas. Ello parece haber afectado incluso a los paneles de mayor monumentalidad, con frisos verticales y motivos de gran tamaño. Curiosamente, dicha 'incapacidad' habría afectado de manera principal a los motivos figurativos: en particular a los zoomorfos y en mucha menor medida a las armas. Así, en la estación de Pedra Xestosa los habitantes de la zona -habiéndose incluso resguardado en el pequeño abrigo- solo percibieron la combinación circular. Esta circunstancia puede estar en el origen de muchas de las destrucciones sufridas por los petroglifos hasta épocas recientes.

Los motivos geométricos habrían pasado menos desapercibidos por asociarse a ítems familia- 
res como ruedas o sartenes. No es casualidad, a nuestro entender, que sean precisamente los que sufren mayor número de destrucciones y/o cristianizaciones (Fig. 12), como en Pedra Escrita (Oia, Pontevedra). Incluso en paneles complejos conformados por motivos de diversa naturaleza, existe una notable tendencia a que cruciformes y otros motivos modernos se concentren en exclusiva o en mayor medida en torno a los elementos geométricos: Pedra da Boullosa, Chan da Lagoa (Campo Lameiro, Pontevedra) o la propia Pedra Xestosa.

Aparicio Casado $(1995,1996)$ ha llegado a conclusiones similares en sus valiosos trabajos acerca del folklore asociado a los petroglifos gallegos. En ellos constata el escaso número de paneles grabados con leyendas o mitos asociados, hecho extensible incluso a las estaciones más emblemáticas. Dicho folklore es indiferente del tipo del motivo si bien, curiosamente, las leyendas se relacionan en su mayoría con cruciformes y motivos modernos. Por ello, sospecha una apli- cación de estos relatos a los petroglifos relativamente moderna, en contraste con los túmulos megalíticos o castros, objeto de la atención y supersticiones del campesinado gallego desde épocas muy remotas (Martinón 2006). La misma carencia se observa en los grandes conjuntos rupestres con representaciones de cérvidos de Baroña (Porto do Son, A Coruña), como A Gurita I, con más de 60 en una roca muy inclinada, y Outeiro Bicudo 1 y 2, con sendos paneles verticales con zoomorfos que, en algún caso, superan el metro de longitud.

Estas observaciones parecen apoyar, efectivamente, nuestra impresión de que buena parte de estas manifestaciones artísticas habrían pasado desapercibidas para las comunidades que habitaron en sus proximidades durante siglos. Lo atribuimos a la inexistencia entre dichas poblaciones de las asociaciones icónicas necesarias para comprender dichas imágenes e incluso para identificarlas como elementos artificialmente producidos.

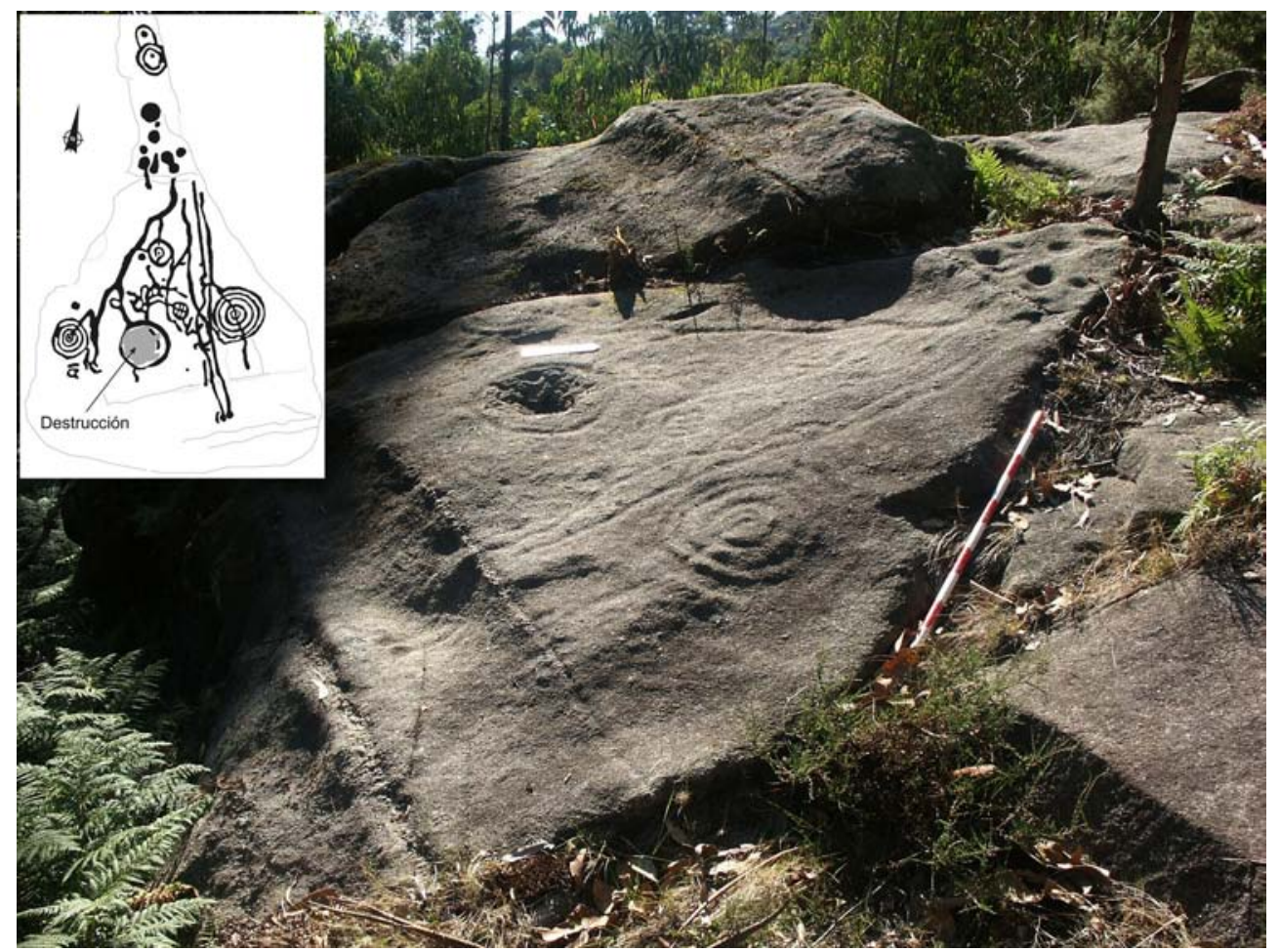

Fig. 12. Aspecto del panel central de Rego de Corzo I (Porto do Son, A Coruña) en el que se observa la destrucción premeditada de una combinación circular, probablemente por motivos simbólicos. Se trata del único incidente de este tipo observado tanto en el propio panel como en los petroglifos del entorno. 


\section{LA AUDIENCIA DE LOS PETROGLIFOS GALLEGOS}

El progreso que se ha vivido en la última década en el campo del arte rupestre aconseja matizar parcialmente ciertas concepciones previas sobre el mismo. Así, la definición del arte rupestre al aire libre como un fenómeno de una naturaleza abierta o accesible (Bradley 2000: 72) debe ser observada ahora con prudencia a tenor de la documentación de grabados en el interior de abrigos. Su aparición nos hace preguntarnos si el arte rupestre galaico habría estado efectivamente asequible a todos los miembros de la comunidad o si habría restricciones en función de la posición social, edad o género de determinados sectores o individuos. Se abre el interrogante, además, de si el arte rupestre habría estado destinado a un único tipo de audiencia o si ésta habría cambiado en función de la naturaleza de cada estación o incluso de cada roca.

Salvo en casos concretos (Bradley 2002, 2009), el análisis de la audiencia en el arte rupestre galaico -es decir, del número y naturaleza de los individuos para cuya observación fue grabado un petroglifo determinado- se ha limitado a dos aspectos: la perceptibilidad del panel (tradicionalmente asociada, como hemos visto, al carácter horizontal o vertical de la superficie grabada) y la disponibilidad de espacio físico para congregar un mayor o menor número de individuos (Vázquez Varela 2000). Una aproximación paradigmática de este tipo es la aplicada a las denominadas 'rocas panoplia' (Peña y Rey 2001): paneles verticales en los que se grabaron un buen número y variedad de representaciones de armas. Estos petroglifos se han asociado reiteradamente a ritos de agregación de determinados individuos, casi siempre guerreros (figura ésta rara vez definida de un modo claro), en cuyo marco se habrían realizado ceremonias iniciáticas o de otro tipo (Vázquez Varela 2000; Peña y Rey 2001; Santos 2005a).

Al tratar la audiencia del arte rupestre galaico, debemos reflexionar primero sobre los mecanismos físicos que pudieron haber actuado a la hora de conformarla. Después, consideraremos el papel de aquellos factores de naturaleza más inmaterial, reconociendo -al igual que otros autores han hecho antes (Bradley 2002)- la dualidad operativa que regiría o condicionaría la audiencia de un determinado petroglifo: una separación física y otra intelectual o simbólica.

\subsection{Mecanismos de conformación de la audiencia en el arte rupestre al aire libre}

Partiendo de la hipótesis de que un grabado rupestre situado al aire libre pudo, no obstante haber estado destinado a una audiencia tan reducida o selecta como el ubicado en el interior de un abrigo, consideramos necesario determinar los mecanismos que habrían incidido en su composición. Por ejemplo, el carácter remoto combinado con la escasa perceptibilidad pueden haber sido dos poderosos elementos de segregación que condicionarían de un modo importante la audiencia de un petroglifo, al requerir del observador el conocimiento del terreno para poder localizarlos.

Ciertos autores han propuesto que los motivos abstractos habrían tenido, de modo general, una ubicación comparativamente más remota, a la que poca gente habría tenido acceso, en contraposición a los motivos naturalistas, que tenderían a emplazarse cerca de las hipotéticas zonas de hábitat, donde la audiencia sería muy diferente (Bradley 1997). El paulatino aumento del catálogo de arte rupestre en Galicia ha evidenciado que, aunque dicha hipótesis no carece de fundamento, existen importantes y numerosas salvedades, como las derivadas de la aparición de representaciones de cérvidos en lugares totalmente aislados así como en el interior de abrigos. La cada vez mayor indiferenciación en la ubicación de motivos abstractos y naturalistas muestra la polivalencia de estas representaciones y la dificultad de definir audiencias solo por el tipo de motivo representado.

Diversos mecanismos o estrategias más allá de la verticalidad del panel o del tamaño de los motivos grabados, habrían permitido aumentar o disminuir la perceptibilidad de un petroglifo, haciéndola incluso independiente de las características físicas y de su ubicación. Un petroglifo situado en las inmediaciones de las zonas habituales de tránsito durante la Prehistoria pudo haber pasado prácticamente desapercibido para buena parte de los individuos que caminaran por el lugar mientras que otros, que hoy se nos antojan apenas visibles, pudieron haber sido mucho más evidentes. 
Tampoco debe despreciarse la importancia que condiciones externas al propio petroglifo, como el momento del día (o del año) o las condiciones atmosféricas, habrían jugado en la percepción de los paneles grabados. Resulta obvio para cualquier investigador del arte rupestre que la observación de los motivos se ve profundamente alterada por las condiciones de luz existentes: la visita con una iluminación adecuada puede hacer visibles motivos de otro modo prácticamente imperceptibles. Además, en aquellas estaciones con paneles o motivos con orientaciones disímiles, la contemplación en distintos momentos del día habría cambiado toda la lectura del petroglifo, ocultando unas imágenes y desvelando otras, renovando así el mensaje transmitido en cada ocasión.

A su vez, la lluvia modifica la tonalidad de la superficie de la roca, facilitando o dificultando la lectura: el petroglifo de Os Mouchos (Rianxo, A Coruña), al mojarse, adquiere una tonalidad rojiza que contrasta profundamente con el color de los surcos, acentuando especialmente la visibilidad de los motivos. El reflejo de la luz del sol sobre la roca mojada también habría aumentado exponencialmente la percepción de los grabados (Fig. 13), no pudiendo descartarse que durante su observación se hubiese mojado la roca como método para interactuar con ella y resaltar unos determinados motivos sobre otros en función de la información concreta que se quisiese transmitir.

La estación de A Insuela (Porto do Son, A Coruña) es uno de los ejemplos más evidentes de

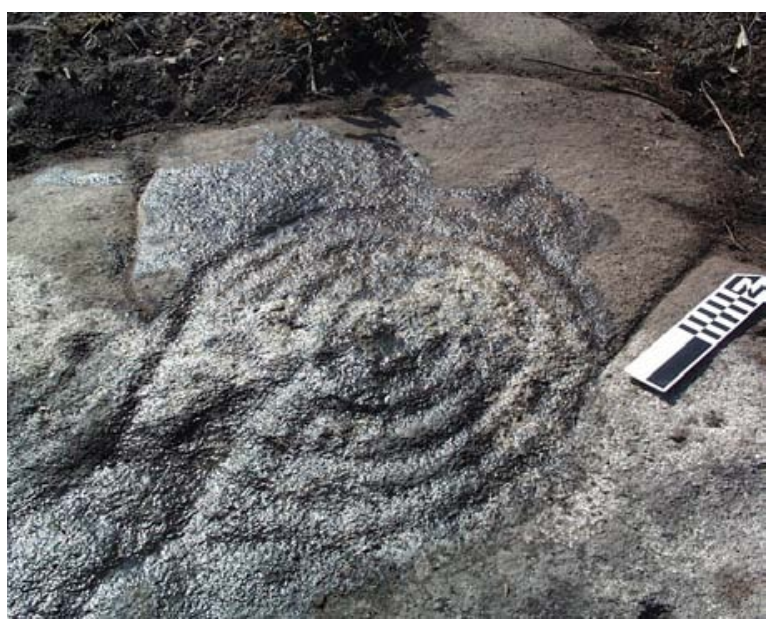

Fig. 13. Combinación circular de Monte de San Miguel (Agolada, Pontevedra) cuya perceptibilidad ha sido notablemente aumentada al humedecer la roca. cómo las condiciones atmosféricas alteran la manera de percibir un petroglifo. En ella dos zoomorfos fueron grabados en torno a una profunda pileta natural (Fig. 14). El agua de lluvia acumulada en su interior habría dotado de gran realismo a la escena, simulando la ubicación de los animales al pie de un curso de agua. El efecto sería aún más realista con las gotas de lluvia salpicando la superficie del agua, al dotar a la escena de cierta movilidad e incluso sonoridad. Dichas impresiones serían radicalmente diferentes sin ella. En este sentido, la similitud con otras escenas de los petroglifos gallegos en las que los zoomorfos se sitúan en torno a combinaciones circulares reforzaría la hipótesis, ya clásica, de que buena parte de estos motivos podrían haber representado cursos o acumulaciones de agua.

Es muy posible que este tipo de circunstancias -que habrían potenciado aspectos de las escenas, como su realismo- fuese una parte fundamental del proceso de visualización. Así, el conocimiento de las condiciones idóneas para la observación de un petroglifo podría haber sido tan importante como el de su emplazamiento a modo de eficaz mecanismo de gestión de la naturaleza de su audiencia mediante la gradación de la profundidad del mensaje y, en último término, del volumen de significado y nivel de impacto transmitidos.

La percepción de los grabados habría dependido en gran medida de una serie de procesos culturalmente mediados, como los conocimientos y recuerdos de los propios individuos que conforman la audiencia. Bajo esta óptica, el observador no era -en muchos aspectos- un agente libre que pudiera moverse alrededor de las imágenes e interactuar con ellas a su antojo, sino que posiblemente debería hacerlo de un modo particular y siguiendo una secuencia correcta. Dicha circunstancia podría haber implicado que, incluso en las estaciones más perceptibles, el acceso a su significado real o último dependiese del conocimiento del ritual o coreografía adecuados que su observación exigía. Ese ritual debe ser entendido como un conjunto de actividades físicas, mentales y emocionales que podrían incluir desde la dirección y modo de acercarse a un petroglifo hasta la manera de colocarse ante él, pasando por el orden en el que deberían ser observados los distintos motivos y escenas que lo componen.

Para un desconocedor del fenómeno rupestre de cierto lugar el proceso habría sido muy diferente, incluso guiado por alguien con experiencia.

Trab. Prehist., 69 N. $^{\circ}$ 1, enero-junio 2012, pp. 80-102, ISSN: 0082-5638

doi: $10.3989 /$ tp.2012.12081 


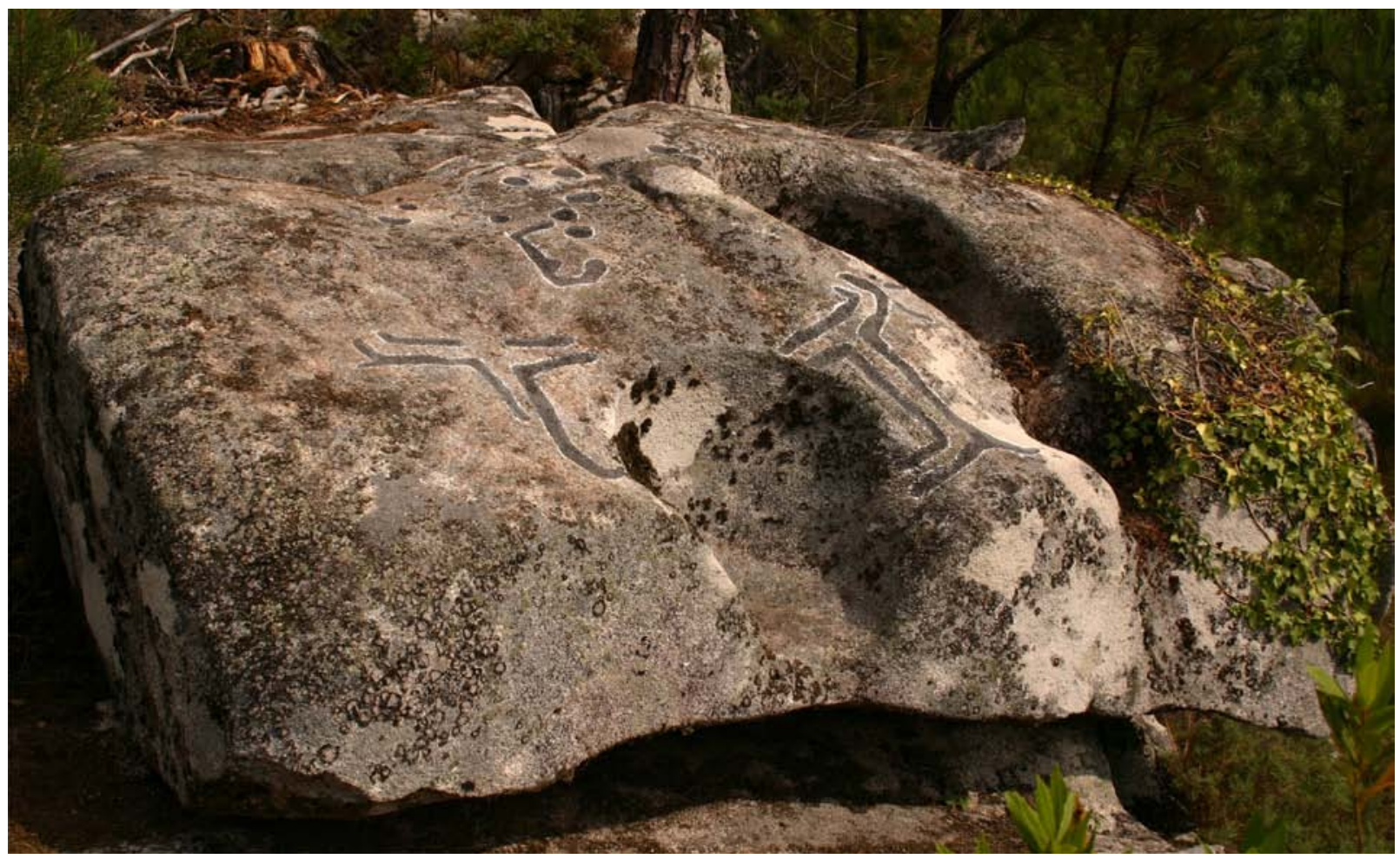

Fig. 14. Aspecto general del petroglifo de A Insuela (Porto do Son, A Coruña). Sendos zoomorfos (acentuados digitalmente) se grabaron en torno a una pileta natural que, una vez llena de agua, habría dotado a la escena de un notable realismo, simulando la ubicación de los propios animales en la naturaleza, abrevando quizás en algún curso de agua o manantial próximo.

Un miembro no iniciado habría sido, en muchos sentidos, equivalente a un ente foráneo de la comunidad, por lo que tendría sentido que el acceso a estos conocimientos fuese una condición sine qua non para formar parte plena de ella, así como la prerrogativa de cederlos o comunicarlos a nuevos individuos una importante fuente de poder o prestigio en el marco del grupo.

Muchos de estos conocimientos pueden haber sido, en parte, descodificables en función de la información aportada por las propias imágenes y, por lo tanto, a priori ser accesibles a todo aquel que los observara, incluidos los propios arqueólogos (como pretenden una parte de las aproximaciones estructuralistas). En cambio otros niveles de entendimiento es muy probable que requiriesen un conocimiento específico, reservado e independiente de los códigos subyacentes.

No obstante, no todas las estaciones conceden el mismo grado de libertad durante el proceso de observación. Una roca horizontal puede permitir numerosas formas de visualización, requiriendo quizás de una participación más activa que invitase a moverse, conocer el punto idóneo donde situarse o cómo rodear el panel para contemplar los motivos del modo y orden correctos. Por el contrario, los paneles verticales o inclinados, al presentar un punto de vista privilegiado (Vázquez Rozas 1995) e incluso único, habrían concedido menos libertad a la audiencia. Esa circunstancia y el que, con frecuencia, las escenas representadas en esos paneles sean de una -aparentemente- fácil comprensión (armas, monta, caza...) nos hacen pensar en que quizás muchos de estos petroglifos habrían sido destinados a audiencias amplias, al menos en parte, con un papel más pasivo y posiblemente menos especializado.

El significado o significados de un petroglifo pudo variar a lo largo de su existencia. El proceso de inclusión de nuevos grabados en un panel posiblemente se hubiese concebido por parte de las poblaciones prehistóricas como un modo de conexión con los individuos que habían realizado el mismo proceso en el pasado (sus 'antepasa- 
dos'), pero durante dicho acto también se estarían integrando nuevas historias que habrían reformulado y recodificado las preexistentes. Además, la inclusión de nuevos motivos modificaría la experiencia previa de los observadores e incluso posiblemente hubiese obligado a renovar la coreografía necesaria para la comprensión del panel. Todo ello habría dado lugar -con toda probabilidad- a nuevos significados que probablemente fuesen desdibujando paulatinamente aquéllos que el petroglifo habría tenido originalmente. El hecho de que los observadores contemporáneos solo contemplamos el resultado final del proceso (Tilley 2008), con frecuencia es obviado por muchos especialistas, que analizan los paneles como si hubiesen sido fruto de una sola mente y ejecutados por una única mano. No obstante, existen ciertos paneles que -por su coherencia y homogeneidad interna- dan la impresión de haber sido efectivamente realizados de acuerdo a una planificación única y posiblemente grabados en un corto lapso de tiempo. Un buen ejemplo sería la escena de caza de Pedra Xestosa.

En último término, el conocimiento sobre el arte rupestre no se materializa únicamente a través del grado de comprensión de los símbolos y escenas que lo conforman sino también mediante el control del propio acto de observación y del influjo de este sobre la audiencia. Tal circunstancia lleva implícita una gran variabilidad, al reconocer la posibilidad de que el significado de un petroglifo no fuera fijo, sino dependiente -en gran medida- de las circunstancias concretas existentes en el momento de su visualización.

El proceso de observación de un petroglifo pudo haber sido altamente variable y profundamente dependiente del dominio de los códigos de visualización por parte del observador. Tal circunstancia introduce en la ecuación una concepción más importante del individuo, entrando en juego su experiencia, conocimientos y recuerdos. La revalorización del individuo implica, asimismo, el reconocimiento de la posibilidad de que cada observador hubiera tenido una experiencia concreta o una visión del fenómeno específica y mutable. Las diferentes audiencias habrían vivido un lugar de distintas maneras e incluso un mismo individuo podría haber experimentado de modo dispar un mismo lugar, en función de los momentos de su vida. Es muy probable que el aprendizaje de los códigos que permitiesen comprender al arte rupestre se actualizase continuamente du- rante la vida de una persona, por lo que su percepción podría cambiar también.

En conclusión, el significado o simbolismo de un petroglifo dependería de una suma de circunstancias contingentes, muchas tan solo intuibles desde una perspectiva actual. Se establece así una concepción en la que se acepta la interactuación entre observador y petroglifo como un proceso en el que ninguno de los dos es un elemento pasivo. Se deja patente la posibilidad de distintos niveles de acceso a los petroglifos al aire libre, desde aquellos destinados a una visión más general y a una audiencia más amplia a otros más 'selectos'. Dicha variabilidad no vendría dada única o principalmente por su temática sino por un conjunto de información que incluiría además las características de la propia roca y su ubicación dentro del paisaje circundante, así como la naturaleza de la audiencia.

Las disquisiciones acerca de la accesibilidad del arte rupestre galaico deben superar la simple dicotomía Arte Público vs. Arte Restringido. La creemos poco operativa durante estos momentos de la Prehistoria, aceptando una gradación mutable y variable entre cada parte en función del paso del tiempo y de la composición de la propia audiencia.

\subsection{Composición de la audiencia de los petroglifos gallegos}

El género se ha establecido de un modo tradicional como la distinción más importante en la conformación de las audiencias que podrían haber accedido (física e intelectualmente) a las estaciones rupestres. Ello deriva de la reiteración de grabados de armas y de escenas de caza o monta que remitirían aparentemente al mundo del varón y de lo masculino (Peña y Rey 2001: 192), en contraste con la ausencia de actividades cotidianas o domésticas (Peña y Rey 2001: 145) que -a tenor de aquellas visiones tradicionales- habrían sido llevadas a cabo por mujeres.

No sabemos si la posible segregación en función del género de los motivos y escenas grabados en las rocas se habría extendido necesariamente a la audiencia. El significado de los motivos de buena parte de las estaciones no está lo suficientemente claro como para negar tajantemente la asociación de alguno al mundo femenino. M. Díaz-Andreu (1998) ha expuesto perfectamente este tipo de sal-

Trab. Prehist., 69, N. ${ }^{\circ}$ 1, enero-junio 2012, pp. 80-102, ISSN: 0082-5638

doi: $10.3989 /$ tp. 2012.12081 
vedades para el caso del arte rupestre levantino, que debe extenderse al propio papel de la mujer en el proceso de grabado de las rocas. Si aceptamos que el elevado grado normativo de las figuras representadas en los petroglifos gallegos derivara de la participación de especialistas en su elaboración (Peña y Rey 2001: 216-217), no debería descartarse que -como ocurre en algunas comunidades actuales de África y Oceanía- entre ellos hubiese habido mujeres (Díaz-Andreu 1998).

La intensidad de la segregación o diferenciación sexual en el seno de las comunidades que habitaron el noroeste de la Península Ibérica durante la Prehistoria Reciente resulta muy difícil de determinar. La escasez de restos orgánicos no nos permite decidir si las divergencias observadas en los ajuares megalíticos responden -efectivamente- a diferencias sexuales. En la esfera doméstica, dicha información resulta aún más inaccesible, pues es todavía muy poca la evidencia con la que contamos. Se ha insinuado la posibilidad de un acceso diferencial a las materias primas líticas que, por su rareza, habrían sido más difíciles de conseguir, por parte de las mujeres con base en la ausencia de determinadas estrategias de explotación (Rodríguez y Fábregas 2011). La hipótesis, de momento, resulta difícil de verificar. Otro tipo de segregación que pudo haber existido derivaría de la edad y, en función de la misma, del estatus de la audiencia en el marco de la comunidad. Estos criterios habrían sido operativos con total seguridad, pero resultan extremadamente complicados de rastrear.

\section{LOS GRABADOS Y EL PAISAJE}

Los especialistas hemos fomentado un tipo de interpretaciones en las que el arte rupestre al aire libre es definido y explicado como mediador entre una comunidad y su entorno inmediato. Los arqueólogos hemos intentado definir la identidad de la propia comunidad y el papel concreto que el arte rupestre habría jugado en la conformación y reforzamiento de la misma a través de las contraposiciones creadas en el marco de dicha relación (rivalidad con comunidades vecinas por la explotación de recursos; Cultura vs. Naturaleza; Espacio doméstico vs. Espacio ritual).

Sin embargo, se ha prestado menos atención a la posibilidad de que los petroglifos hayan sido, en buena medida, una herramienta generada y usada exclusivamente en el seno de la sociedad que los creó para reforzar una visión del mundo propia y negociar el papel que la comunidad tendría en la misma, sin ser estrictamente necesario contraponerla a ningún tipo de alteridad (naturaleza u otros grupos competidores). Así, por ejemplo, en un primer momento, los individuos de una comunidad solo podrían haber accedido a los petroglifos gracias a la mediación de otros miembros más experimentados. Sería a través de dicho proceso de conocimiento como un individuo concreto podría haber sido iniciado en la información práctica y simbólica, recurriendo a recuerdos o episodios míticos asociados no solo con el petroglifo en sí sino con el paisaje circundante. De esa manera, petroglifo y paisaje se asociarían irremediablemente a la comunidad en función de una historia en común.

La interacción de una comunidad con los petroglifos no debe ser entendida en exclusiva como aquellas actividades estrictamente realizadas en las inmediaciones de los grabados, sino como una suma de procesos que puede iniciarse con las circunstancias del propio desplazamiento hasta la estación rupestre. El hecho de que muchas insculturas solo sean perfectamente visibles a primera hora de la mañana o en el ocaso podría haber implicado viajar en la oscuridad, cuando el mundo y su percepción por parte del individuo son distintos. Este conjunto de experiencias implicadas en el acceso y visualización de los motivos habría sido, quizás, tan o más importante que las características de los grabados y los ritos realizados en torno a ellos.

Los territorios pueden ser a menudo entendidos más como un conjunto de lugares específicos con un significado especial para una comunidad concreta que como espacio abstracto con fronteras nítidamente establecidas. Por ello no cabe descartar que los petroglifos puedan haberse establecido precisamente como locales de este tipo. Su recorrido en una secuencia determinada podría haberse reivindicado como un acto simbólico en sí mismo, estructurando las experiencias de los propios lugares que unen y ayudando a establecer una especie de orden en los mismos (Tilley 1994: 39), tipificado por los miembros pasados de la comunidad.

La inclusión de nuevos lugares habría sido prerrogativa de los individuos con una mayor preeminencia en el marco de la comunidad y en ellos reposaría también el conocimiento experto

Trab. Prehist., 69, N. ${ }^{\text {1 }}$ 1, enero-junio 2012, pp. 80-102, ISSN: 0082-5638 doi: $10.3989 /$ tp.2012.12081 
sobre estos lugares así como su mantenimiento. Dichos saberes habrían sido una probable fuente de poder para el individuo al otorgarle el control sobre la difusión de la información acerca del territorio circundante y sobre el origen y naturaleza de los lazos que la comunidad mantendría con el mismo con base en una historia común.

Es posible que en el arte rupestre galaico al aire libre hubiese existido cierta transposición entre el panel grabado y el lugar que ocupa (Tilley 1994). Con ello se produciría un reforzamiento mutuo del petroglifo y del paisaje circundante que acentuaría, por un lado, la propia cualidad narrativa del panel y reforzaría la credibilidad de su mensaje al vincular la acción representada a un 'escenario de los hechos' cercano y conocido por la audiencia. Al mismo tiempo, es posible que dichos acontecimientos hubiesen sido importantes en la historia o mitología de la comunidad, por lo que se reforzaría la importancia de dicho local para el grupo por haber sido, precisamente, el escenario de los mismos. Por medio de estos relatos, sociedad y espacio quedarían intrínsecamente ligados, convirtiéndose este último en lo que Tilley (1994: 15) denomina 'espacio existencial', construido a través de las experiencias concretas de los individuos y socializadas a través del grupo, en constante proceso de producción y reproducción, generado a partir del orden cotidiano.

Los lugares presentan diferentes densidades de significados para sus habitantes, en función de los eventos y acciones de los que fueron escenario y que forman parte de la memoria común. A mayor número y estabilidad de los significados asociados a un lugar, más profundo será el nexo con el mismo por parte de la comunidad. Si consideramos que el grabado de los petroglifos puede tener que ver con el desarrollo por parte de las comunidades de asociaciones simbólicas y mitológicas, éste actuará como transformador de algo físico o geográfico en algo experimentado histórica y socialmente, como recordatorio de las acciones históricas de individuos o sociedades (Tilley 1994).

Un buen ejemplo de esta posible transposición entre panel y espacio circundante podría ser la impresión -repetidamente señalada por los especialistas (Vázquez Rozas 1997; Peña y Rey 2001) - de que en determinadas estaciones (la propia Pedra Xestosa o Pozas da Garda; Figs. 4 y 15) la ubicación de los ciervos dentro del panel parece reproducir la orografía del entorno inmediato: son representados subiendo o bajando en la dirección de la pendiente del terreno donde se emplaza la roca. En otras ocasiones, la inclinación de la superficie del panel es idéntica a la de la ladera donde se sitúa y por la que probablemente habrían circulado los animales grabados (Vázquez Rozas 1997: 72).

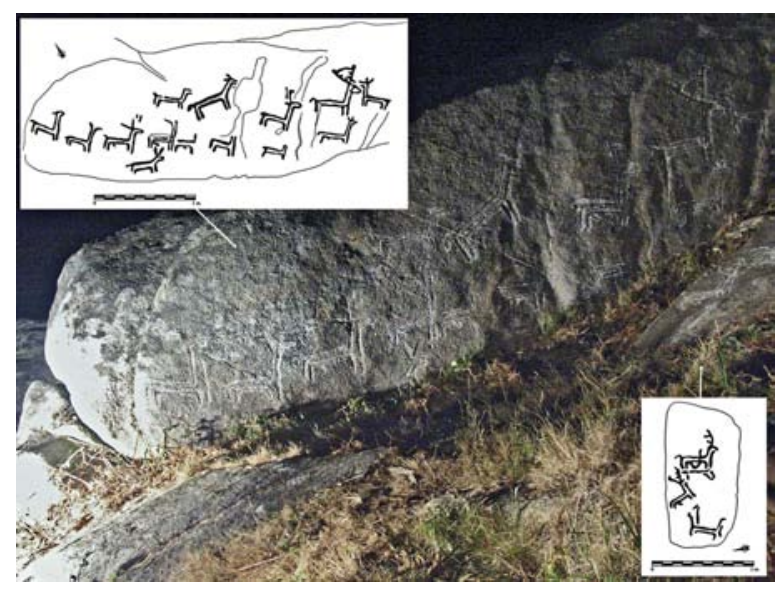

Fig. 15. Aspecto general del panel vertical y de la roca anexa de Pozas da Garda (Porto do Son, A Coruña). La disposición de los cérvidos en el panel imita la orografía del entorno en el que se sitúa la propia estación.

\section{VARIABILIDAD Y POLISEMIA DEL ARTE RUPESTRE GALAICO}

Una de las características fundamentales del arte rupestre galaico es su enorme variabilidad y su profundo carácter polisémico, patentes en su naturaleza (características de los motivos, morfología y dimensión de los paneles, perceptibilidad de ambos, etc.) y su ubicación espacial.

Existe una enorme multitud de figuras geométricas y naturalistas consideradas portadoras de distintos mensajes y significados y a las que se les han atribuido incluso cronologías diversas (Santos 2005b). Es posible que muchos de estos motivos hayan tenido un significado más o menos permanente mientras que el de otros fuese polivalente y mutable. Sin embargo, dicha diferenciación no residiría, en último término, en las características del propio motivo. El grabado de una alabarda o un antropomorfo habría podido tener, posiblemente, un menor rango de significados que un círculo simple o un grupo de cazoletas. Pero ello no excluye que cambiara en función de un buen núme- 
ro de variables. El arte rupestre habría sido un nexo relacional de las imágenes representadas, las cualidades materiales de la roca y los paisajes circundantes (Tilley 2008: 20).

Esta naturaleza sería profundamente variable y mutable sincrónica y diacrónicamente en función de las propias características de su audiencia particular (cantidad, composición y nivel de dominio del código por parte de la misma). Es posible que en una misma estación hubiesen existido varios niveles de significado, desde información práctica para el acceso a ciertos recursos hasta conocimientos sagrados, accesibles en función del dominio del código que poseyesen los observadores (Bradley 2002). Los motivos no serían abstractos, ya que su interpretación no dependería de la arbitrariedad del observador, sino del acceso a la instrucción sobre su significado o significados, sien- do factible que diferentes individuos hubiesen poseído distintos niveles de habilidad o conocimiento para interpretarlos (Bradley 2009: 44). Esta contingencia podría incluso afectar a las imágenes más naturalistas.

Esa variabilidad puede observarse también en la ubicación de los petroglifos. En algunas áreas del territorio gallego, como Campo Lameiro (Pontevedra), existen concentraciones de estaciones rupestres de una enorme diversidad respecto a su monumentalidad, características generales y ubicación. Otro claro ejemplo son yacimientos que se presentan en este trabajo: el abrigo de Rego de Corzo se ubica en un área con una espectacular concentración de arte rupestre. Allí conviven petroglifos de especial complejidad y monumentalidad, como los frisos verticales de Outeiro Campelos y Campo Grande (Fig. 16), en

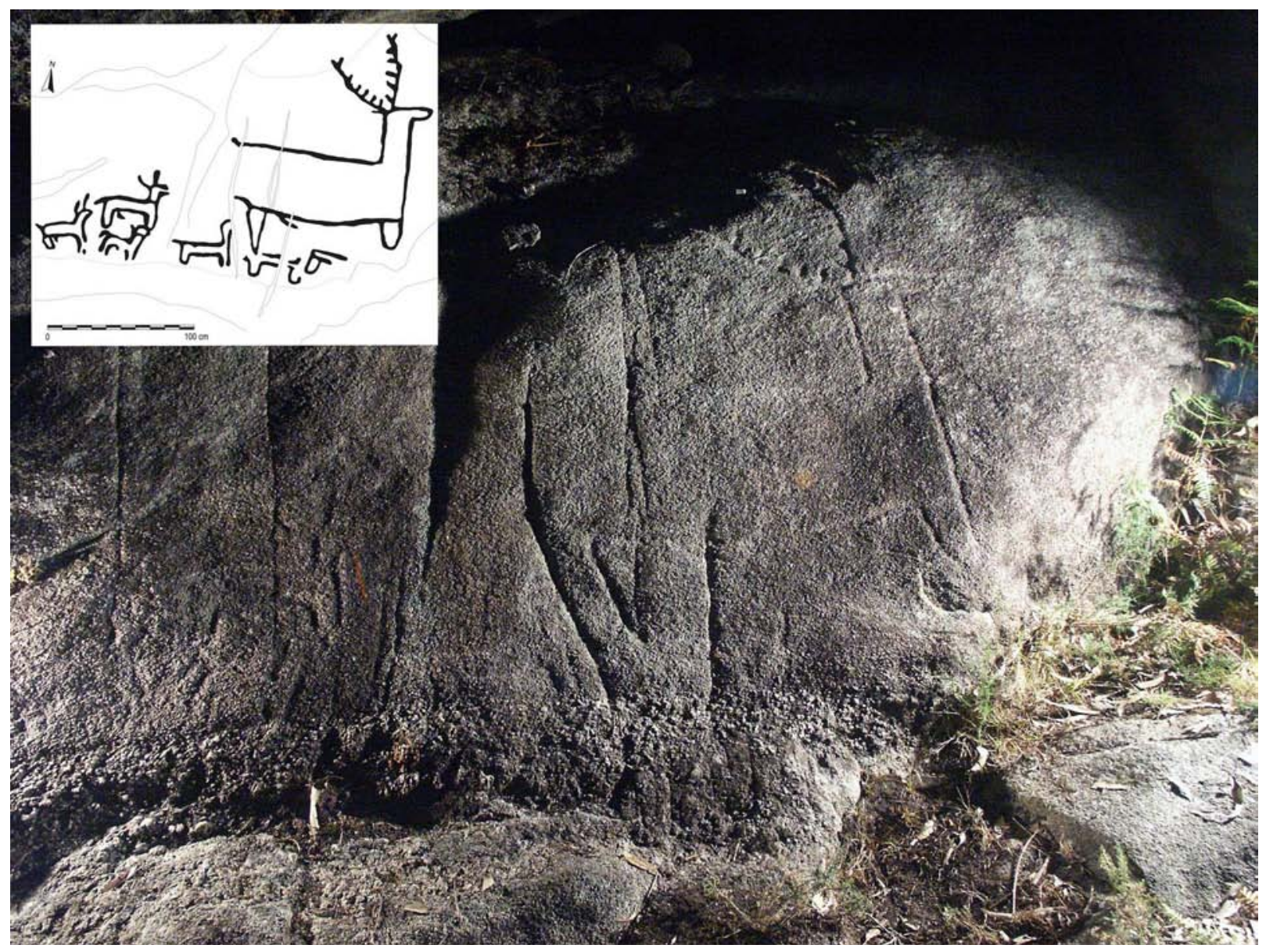

Fig. 16. Aspecto general del panel vertical de Campo Grande I (Porto do Son, A Coruña). 
los que fueron grabados zoomorfos de hasta 135 $\mathrm{cm}$ de altura, o el conjunto de Rego de Corzo I y III, con multitud de motivos entre los que se incluye una escena de monta junto a otros de gran simplicidad, como cazoletas aisladas o círculos simples. Los abrigos de Calderramos y Outeiro de Rixidores se sitúan en las inmediaciones de paneles verticales o inclinados en los que se grabaron zoomorfos, próximos a insculturas muy sencillas, compuestas apenas por un círculo simple o varias cazoletas. El ejemplo de Pedra Xestosa es, si cabe, más revelador: en un mismo afloramiento dos paneles de una notable verticalidad y gran complejidad coexisten con otro -el situado en el interior del pequeño abrigo- conformado por un círculo y un cérvido.

La convivencia en un mismo territorio, y en ocasiones en una misma estación, de paneles con monumentalidad y perceptibilidad muy variadas, es muy posible que nos esté revelando el diverso papel o la naturaleza distintiva de cada uno de ellos. Resulta muy probable que hubiese existido una compleja variabilidad que explicaría por qué se habrían dibujado determinados motivos en lugares concretos. Sería una serie de circunstancias enormemente mutables las que darían su significado último al petroglifo y consideramos que estas no pueden ser aprehendidas desde paradigmas rígidos que no contemplen dicha variabilidad y la complejidad de unos procesos que, en buena parte, derivan del hecho de que las acciones de grabado y la propia observación habrían sido el resultado de episodios individuales con un carácter acumulativo.

\section{CONCLUSIONES}

La aparición de grabados rupestres de tipo galaico en el interior de abrigos graníticos evidencia, por primera vez, la existencia de restricciones físicas para la observación de este fenómeno, al tiempo que deja claro que los petroglifos del Noroeste de la Península Ibérica no se ha desarrollado en exclusiva al aire libre. Dicha circunstancia introduce nuevas posibilidades para su análisis al tiempo que permite matizar algunas de las interpretaciones al uso sobre este fenómeno artístico.

La documentación de motivos propios del corpus principal del arte rupestre galaico en el interior de cavidades de reducido tamaño nos ha permitido reflexionar sobre las diferentes audiencias a las que estarían destinados los petroglifos. Estas pueden haber cambiado en función de las características concretas de cada estación grabada pero también de otras circunstancias que habrían hecho posible que un mismo panel hubiese tenido distintos niveles de significado accesibles a audiencias diversas dependiendo del dominio de ciertos códigos por parte de las mismas. Estas condiciones habrían sido independientes de las restricciones físicas para la observación de los grabados y podrían haber afectado, por lo tanto, a la totalidad del arte rupestre galaico.

La identificación de estrategias para modular el grado de perceptibilidad de los petroglifos hace posible que muchos hubiesen sido voluntariamente ocultados a la mayoría de los potenciales observadores. La hipótesis alcanza su evidencia más clara en la propia actividad grabadora en el interior de cavidades. Esta faceta del arte rupestre galaico, no como algo abierto y accesible sino oculto y reservado, obligará a matizar las interpretaciones que han asociado este fenómeno a un papel de marcador del paisaje prehistórico y a un mecanismo de interacción y mediación entre las distintas comunidades que lo habitaron.

Consideramos que, en el Noroeste, la ausencia de arte en el interior de abrigos se ha debido, fundamentalmente, a la falta de su búsqueda específica del mismo por parte de los investigadores, en la idea de que el arte rupestre de esta región se había configurado como un fenómeno exclusivamente al aire libre. Es posible que a partir de la publicación de este artículo aparezcan nuevos ejemplos en otros puntos de Galicia.

\section{AGRADECIMIENTOS}

Las investigaciones que han hecho posible este artículo han sido llevadas a cabo en el marco del proyecto Ocupación do Espazo e Modificación do Entorno na Península do Barbanza durante a Prehistoria Recente. Os petroglifos de Porto do Son, financiado por el Ministerio de Ciencia y Tecnología y la Dirección Xeral de Investigación e Desenvolvemento de la Consellería de Innovación, Industria e Comercio de la Xunta de Galicia. Así mismo, agradecemos profundamente a José Cernadas Sande, descubridor del abrigo de Outeiro de Rixidores, su valiosa 
colaboración durante la realización de este artículo.

\section{BIBLIOGRAFÍA}

Aparicio Casado, B. 1995: "Etnoarqueología de los grabados rupestres de la provincia de Pontevedra". Actas del XXII Congreso Nacional de Arqueología (Vigo 1993) 2: 111-116. Vigo.

Aparicio Casado, B. 1996: "La interpretación popular de los grabados rupestres gallegos". En A. A. Rodríguez Casal (ed.): Humanitas: estudios en homenaxe ó Prof. Dr. Carlos Alonso del Real. Universidade de Santiago de Compostela. Santiago de Compostela: 257-284.

Bahn, P. 2001: "Save the Last Trance for Me: An Assessment of the Misuse of Shamanism in Rock Art Studies". En H. P. Francfort, R. N. Hamayon y P. G. Bahn (eds.): The Concept of Shamanism: Uses and Abuses. Akadémiai Kiadó. Budapest: 51-94.

Bradley, R. 1997: Rock art and the prehistory of Atlantic Europe: singing the land. Routledge. Londres.

Bradley, R. 1998: The significance of monuments. On the shaping of human experience in Neolithic and Bronze Age Europe. Routledge. Londres.

Bradley, R. 2000: An archaeology of natural places. Routledge. Londres.

Bradley, R. 2002: "Access, style and imagery: the audience for prehistoric rock art in Atlantic Spain and Portugal, 4000-2000 BC". Oxford Journal of Archaeology 21 (3): 231-247.

Bradley, R. 2009: Image and Audience. Rethinking Prehistoric Art. Oxford University Press. Oxford.

Bradley, R.; Criado Boado, F. y Fábregas Valcarce, R. 1994: "Rock art research as landscape archaeology: a pilot study in Galicia, north-west Spain". World Archaeology 25: 374-390.

Bradley, R. y Fábregas, R. 1999: "La ley de la frontera: grupos rupestres galaico y esquemático y prehistoria del Noroeste de la Península". Trabajos de Prehistoria 56 (1): 103-114.

Casimir, M. J. 1992: "The determinants of rights to pasture: territorial organization and ecological constraints". En M. J. Casimir y A. Rao (eds.): Mobility and territoriality: social and spatial boundaries among foragers, fishers, pastoralists, and peripatetics. Berg. Nueva York: 153-203.

Cernadas Sande, J. 2007: Gravados rupestres nos montes de Carnota. TresCTres. Santa Comba.

Criado Boado, F. y Vaquero Lastres, J. 1993: "Monumentos, nudos en el pañuelo, Megalitos, nudos en el espacio: Análisis del emplazamiento de los monumentos tumulares gallegos". Espacio, tiempo y forma. Serie I, Prehistoria y arqueología 6: 205248.
Darvill, T. 2002: "White on blonde: quartz pebbles and the use of quartz at Neolithic monuments in the Isle of Man and Beyond". En A. Jones y G. MacGregor (eds.): Colouring The Past. The significance of colour in archaeological research. Berg. Nueva York: 73-92.

Díaz-Andreu García, M. 1998: "Iberian post-palaeolithic art and gender: discussing human representations in Levantine art". Journal of Iberian Archaeo$\log y$ 0: 33-52.

Eguileta Franco, J. M.; Fernández Ibáñez, C. y Seara Carballo, A. 1993-1994: "Un campaniforme cordado procedente de A Limia (Ourense)". Brigantium 8: 57-68.

Fábregas Valcarce, R. 2010: Os petróglifos e o seu contexto. Un exemplo da Galicia meridional. Instituto de Estudios Vigueses. Vigo.

Fábregas Valcarce, R.; Rodríguez Rellán, C. y Rodríguez Álvarez, E. 2010: "New approaches to the configuration and the spatial distribution of prehistoric rock art in the North of the Barbanza Peninsula (Galicia, NW of Spain)". En A. Bettencourt, M. J. Sanches., L. B. Alves y R. Fábregas Valcarce (eds.): Conceptualising Space and Place: On the role of agency, memory and identity in the construction of space from the Upper Palaeolithic to the Iron Age in Europe. British Archaeological Reports International Series 2058, Archaeopress. Oxford: 133-140.

Forteza González, M.; García Sanjuán, L.; Hernández Arnedo, M. J.; Salguero Palma, J.; Wheatley, D. W. 2008: "El cuarzo como material votivo y arquitectónico en el complejo funerario megalítico de Palacio III (Almadén de la Plata, Sevilla): análisis contextual y mineralógico". Trabajos de Prehistoria 65 (2): 137-150.

Gómez Fernández, A. y Vázquez Domínguez, M. 2009: "La ocupación romana del yacimiento de Castelo de Chás: A Cova dos Mouros (Oimbra, Ourense)". Gallaecia 28: 139-150.

Guerra Doce, E. y López Sáez, J. A. 2006: “El registro arqueobotánico de plantas psicoactivas en la prehistoria de la Península Ibérica. Una aproximación etnobotánica y fitoquímica a la interpretación de la evidencia". Complutum 17: 7-24.

Ingold, T. 1987: The appropriation of nature: essays on human ecology and social relations. University of Iowa Press, Iowa City.

Insoll, T. 2004: Archaeology, Ritual, Religion. Routledge. Londres.

Kehoe, A. 2000: Shamans and Religion: An anthropological Exploration in Critical Thinking. Waveland Press. Londres.

Lewis-Williams, D. 2002: The Mind in the Cave: consciousness and the origins of art. Thames and Hudson. Londres. 
Mañana Borrazás, P. y Santos Estévez, M. 2002: “Arte rupestre no Promontorio de Corme (Ponteceso)". Gallaecia 21: 115-126.

Martinón Torres, M. 2006: "On the life-histories of megaliths in Northwest Iberia”. En A. A. Rodríguez Casal (ed.): Mégalithisme atlantique. The Atlantic megaliths. Acts of the XIVth UISPP Congress (Liege, Belgium, 2001), British Archaeological Reports, International Series 1521, Archaeopress. Oxford: 4351.

Peña Santos, A. de la y Rey García, M. 2001: Petroglifos de Galicia. Vía Láctea. A Coruña.

Ramil Rego, E. y Ramil Soneira, J. 1995: “A Pena Grande (Santaballa, Villalba), un yacimiento de finales del Paleolítico al norte de la provincia de Lugo". En Actas del XXII Congreso Nacional de Arqueología (Vigo, 1993) 1: 351-356. Vigo.

Rodríguez Rellán, C. y Fábregas Valcarce, R. 2011: "La industria lítica en el Noroeste de la Península Ibérica durante el III y el II Milenios a.C." En M. P. Prieto-Martínez y L. Salanova (eds.): Las comunidades campaniformes en Galicia. Cambios sociales en el III y II Milenios BC en el NW de la Península Ibérica. Diputación Provincial de Pontevedra. Pontevedra: 249-258.

Rodríguez Rellán, C.; Fábregas Valcarce, R.; Eiroa Pose, A.; Rodríguez Álvarez, E. y Gorgoso López, L. 2010: "Alén da fronteira naturalista na arte rupestre galega: estacións con zoomorfos na Costa da Morte (A Coruña)". Gallaecia 29: 83-102.

Rodríguez Saiz, E.; Hidalgo Cuñarro, J. M. y Suárez Otero, J. 1996-1997: "Nuevos datos sobre prehistoria viguesa: estudio de los materiales arqueológicos de las cavidades de 'O Folón' (Coruxo)". Castrelos: Revista do Museo Municipal 'Quiñones de León' 9-10: 55-80.

Santos Estévez, M. 1999: "A arte rupestre e a construcción dos territorios na Idade do Bronce en Galicia". Gallaecia 18: 103-118.

Santos Estévez, M. 2005a: "La caza ritual en la Edad del Bronce y su representación en el arte rupestre de Galicia". En M. Santos Estévez y A. Troncoso Meléndez (eds.): Reflexiones sobre el Arte Rupestre, paisaje, forma y contenido. Traballos de Arqueoloxía e Patrimonio 33, Instituto de Estudios Galegos Padre Sarmiento, CSIC - Xunta de Galicia. Santiago: 83-100.
Santos Estévez, M. 2005b: "Sobre la cronología del arte rupestre atlántico en Galicia”. Arqueoweb (Revista Electrónica) 7(2), sept./dic. 2005. http://www.ucm. es/info/arqueoweb/pdf/7-2/santos.pdf (consulta 21IX-2011).

Scarre, C. 2002: "Epilogue: Colour and Materiality in Prehistoric Society". En A. Jones y G. MacGregor (eds.): Colouring The Past. The significance of colour in archaeological research. Berg. Nueva York: 227-242.

Suárez Otero, J. 1997: "Del yacimiento de A Cunchosa al Neolítico en Galicia. Primera aproximación al contexto cultural de la aparición del Megalitismo en Galicia". En A. A. Rodríguez Casal (ed.): O neolitico atlántico e as orixes do megalitismo: actas do Coloquio Internacional. (Santiago de Compostela, 1996): 485-506. Santiago de Compostela.

Taçon, P. 1994: "Socializing landscapes: the long term implications of signs, symbols and marks on the land". Archaeology in Oceania 29: 117-129.

Tilley, C. 1994: A Phenomenology of Landscape: Places, Paths and Monuments. Berg. Oxford.

Tilley, C. 2004: The Materiality of Stone: Explorations in landscape phenomenology 1. Berg. Oxford.

Tilley, C. 2008: Body and Image: Explorations in landscape phenomenology 2. Left Coast Press. California.

Vázquez Rozas, R. 1995: "Los petroglifos gallegos: selección de su emplazamiento y selección de las rocas grabadas". En Actas del XXII Congreso Nacional de Arqueología (Vigo, 1993) 1: 69-76. Vigo.

Vázquez Rozas, R. 1997: Petroglifos de las Rías Baixas gallegas: análisis artístico de un arte prehistórico. Diputación Provincial de Pontevedra. Pontevedra.

Vázquez Rozas, R. 1998: "El significado de los petroglifos”. En F. J. Costas y J. M. Hidalgo (eds.): Reflexiones sobre el arte rupestre prehistórico de Galicia. Asociación Arqueológica Viguesa. Vigo: 43-68.

Vázquez Varela, J. M. 2000: “Significados y funciones de los grabados rupestres prehistóricos de armas metálicas en el Noroeste de la Península Ibérica”. Cuadernos de Estudios Gallegos 47/113: 9-25.

Vilaseco Vázquez, X. I. y Fábregas Valcarce, R. 2008: "Dos finais do II Milenio A.C. á Segunda Idade do Ferro: o asentamento fortificado de Os Pericos (Ribeira, A Coruña)". Gallaecia 27: 89-112. 